\title{
Application of the rainbow trout derived intestinal cell line (RTgutGC) for ecotoxicological studies: molecular and cellular responses following exposure to copper
}

\author{
Laura M. Langan ${ }^{1} \cdot$ Glenn M. Harper $^{2} \cdot$ Stewart F. Owen $^{3} \cdot$ Wendy M. Purcell ${ }^{4}$.

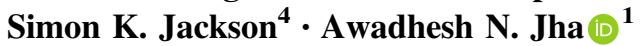

Accepted: 13 July 2017 / Published online: 7 August 2017

(C) The Author(s) 2017. This article is an open access publication

\begin{abstract}
There is an acknowledged need for in vitro fish intestinal model to help understand dietary exposure to chemicals in the aquatic environment. The presence and use of such models is however largely restrictive due to technical difficulties in the culturing of enterocytes in general and the availability of appropriate established cell lines in particular. In this study, the rainbow trout (Oncorhynchus mykiss) intestinal derived cell line (RTgutGC) was used as a surrogate for the "gut sac" method. To facilitate comparison, RTgutGC cells were grown as monolayers (double-seeded) on permeable Transwell supports leading to a twocompartment intestinal model consisting of polarised epithelium. This two-compartment model divides the system into an upper apical (lumen) and a lower basolateral (portal blood) compartment. In our studies, these cells stained weakly for mucosubstances, expressed the tight junction protein ZO-1 in addition to E-cadherin and revealed the presence of polarised epithelium in addition to microvilli protrusions. The cells also revealed a comparable transepithelial electrical resistance (TEER) to the in vivo
\end{abstract}

Electronic supplementary material The online version of this article (doi:10.1007/s10646-017-1838-8) contains supplementary material, which is available to authorized users.

Awadhesh N. Jha

a.jha@plymouth.ac.uk

1 School of Biological and Marine Sciences, University of Plymouth, Plymouth PL4 8AA, UK

2 Electron Microscopy Unit, Faculty of Science and Engineering, University of Plymouth, Plymouth PL4 8AA, UK

3 AstraZeneca, Alderly Park, Macclesfield, Cheshire SK10 4TF, UK

4 School of Biomedical and Health Care Sciences, University of Plymouth, Plymouth PL4 8AA, UK situation. Importantly, the cell line tolerated apical saline (1:1 ratio) thus mimicking the intact organ to allow assessment of uptake of compounds across the intestine. Following an exposure over $72 \mathrm{~h}$, our study demonstrated that the RTgutGC cell line under sub-lethal concentrations of copper sulphate $(\mathrm{Cu})$ and modified saline solutions demonstrated uptake of the metal with saturation levels comparable to short term ex situ gut sac preparations. Gene expression analysis revealed no significant influence of $\mathrm{pH}$ or time on mRNA expression levels of key stress related genes (i.e. CYP3A, GST, $m t A, P g p$ and $S O D$ ) in the Transwell model. However, significant positive correlations were found between all genes investigated suggesting a cooperative relationship amongst the genes studied. When the outlined characteristics of the cell line are combined with the division of compartments, the RTgutGC double seeded model represents a potential animal replacement model for ecotoxicological studies. Overall, this model could be used to study the effects and predict aquatic gastrointestinal permeability of metals and other environmentally relevant contaminants in a cost effective and high throughput manner.

Keywords Ecotoxicology $\cdot$ Animal replacement $\cdot$ in vitro $\cdot$ Rainbow trout $\cdot$ RTgutGC $\cdot$ Dietary $\cdot$ Copper

\section{Introduction}

There is a great societal need for better understanding and monitoring of environmental contaminants discharged in the aquatic systems and their potential impact on the organisms (Donnachie et al. 2016; Jha 2008, 2004). Tissue 
and cell culture systems have been used for progressing the fundamental understanding of biological processes in controlled artificial environments, outside an animal's systemic control (Heikkinen et al. 2010; Eisenbrand et al. 2002). Information obtained using these in vitro models aid in understanding ecotoxicological principles (Burden et al. 2015a; Castaño et al. 2003). With the development of these high throughput systems which could potentially replace the use of animal tests, the number of cell lines currently in existence is vast. The American Type Culture Collection (ATCC) currently holds over 4000 cell lines from 150 different species, with an unsurprising dominance of human derived cell lines (http://www.attc.org/). Fish cell lines have been useful in many areas of research, with their development originally to support aquatic animal viral diseases identification and treatment (Wolf and Quimby 1962).

Rachlin and Perlmutter (1968) first proposed the use of fish cell lines as an in vitro tool for the assessment of toxicity of environmental pollutants to aquatic biota, but it has only been recently that their use has grown tremendously. This is reflected in the wide variety of freshwater and marine species in addition to tissues of origin over an array of applications including fish immunology (Fierro-Castro et al. 2012), toxicology/ecotoxicology (Castaño et al. 2003), biotechnology and aquaculture (Kawano et al. 2011). In comparison to mammalian cell lines, fish cell lines are easier to maintain, manipulate, and produce highly reproducible results. In 1994, Fryer and Lannan reported some 159 fish cell lines (marine and freshwater), with Lakra et al. reporting a further 124 newly established cell lines by 2011 . Despite the widespread need for replacement of animals in toxicity testing across all scientific disciplines, environmental contaminants such as metals, pharmaceuticals or chemicals are rarely assessed in vitro, not even for screening purposes. However, with the strict implementation of the 3Rs (Reduce, Refine and Replace) approach, societal and ethical constraints in addition to economic implications, there is a growing demand for in vitro assays or other procedures to reduce the number of fish used for assessing the ecotoxicity of chemicals. Recently, there has been a combined effort from academia and industry to propose new strategies to reduce the number of fish in acute toxicity tests (Burden et al. 2015a, 2014; Scholz et al. 2013; Hutchinson 2008; Jeram et al. 2005). Burden et al. (2015b) summarises several initiatives currently under way to improve confidence in newer alternative methods, which will support a move towards a future where less data from animal tests is required in the assessment of chemical safety. There is an opportunity to further this trend with the search for appropriate in vitro models of different organ systems to better understand the physiology of fish.
The intestine of a fish is a multifunctional organ (Jutfelt 2011; Grosell et al. 2010) responsible for the absorption of nutrients, ionic and osmotic regulation in addition to functioning as a barrier to keep unwanted agents such as a pathogens, toxins and microorganisms out. Knowledge of fish intestines has been obtained through a variety of different means using a large number of animals, with uptake/ absorption studies primarily addressed using either flow through systems or through the use of short term ex situ methods such as the"gut sac" model. This well used technique allows the manipulation of both mucosal and serosal solutions and has been employed to understand mechanistic action of metal antagonists in fish (Nadella et al. 2011; Ojo and Wood 2007; Nadella et al. 2006a, b), in addition to pharmaceutical uptake in other organisms (Dixit et al. 2012; Mariappan and Singh 2004). However, it is potentially limited in terms of reduced cell viability, loss of enzymatic activity and limited exposure and sampling time (2-4h) (Alam et al. 2012), in addition to requiring the sacrifice of an animal. In terms of xenobiotic metabolism, or its protective function against toxic action, knowledge of key factors governing xenobiotic/toxicant metabolism is far from complete.

Currently, intestinal epithelial models are based on the culture of a suitable cell type directly on flat, porous supports such as Transwell inserts. Among the available models, Caco-2 cell monolayers is one of the best studied approaches and is considered the gold standard for predicting in vitro intestinal permeability and absorption for mammalian studies (Vllasaliu et al. 2014; Gupta et al. 2013; Hubatsch et al. 2007; Gan and Thakker 1997; Bailey et al. 1996). Intestinal cells, such as the Caco- 2 cell line, are typically grown single seeded on Transwell inserts and allowed to differentiate for up to 21 days prior to experiment initiation. However, the Caco-2 cell culture method has had numerous improvements proposed (Ferruzza et al. 2012; Galkin et al. 2008; Anna et al. 2003; Yamashita et al. 2002) to overcome the variability and heterogeneity visible in the literature in terms of performance (for review see Sambuy et al. 2005). Although little information is currently available in the literature, double seeding of the same cell line might reduce the requirement for extra nutrients or expensive additives allowing for the development of polarised, differentiated cells in a comparatively shorter time facilitating potential future high throughput requirements. Indeed, the use of double seeding techniques is a common practice in cell culture methods of fish epithelial cells (Schnell et al. 2016; Stott et al. 2015; Wood et al. 2002).

There is currently one available intestinal cell line derived from the rainbow trout, Oncorhynchus mykiss (Kawano et al. 2011), but our knowledge of this cell line is far from complete. Active transport mechanisms in the form 
of ATP binding cassette (ABC) transporters have been confirmed (Fischer et al. 2011) in addition to majorhistocompatibility genes (Kawano et al. 2010). However, to our knowledge, its ability to function as an in vitro toxicity tool is limited to two studies. Catherine Tee et al. (2011) investigated the response of the RTgutGC cell line to a contaminant in the form of a dark blue colorant (Acid Blue 80) exposed to a monolayer, but found another cell line to be more sensitive while Geppert et al. (2016) investigated nanoparticle transport in the cell line using a twocompartment barrier model. While nanoparticle uptake was confirmed in this model, it is interesting to note that the standardised methodology of the Caco- 2 cell line was employed, namely the growth of the cells over a 21 day period.

Metal metabolism within an organism has a significant effect on their accumulation, distribution and toxicity, with fish known to be particularly sensitive to many waterborne pollutants. Copper $(\mathrm{Cu})$ is a ubiquitous major toxicant in the aquatic environment, and of greater environmental concern compared to other contaminants such as pharmaceuticals (Donnachie et al. 2016). It is also recognised as one of the best-studied metal micronutrient transport systems in the fish intestine (Bakke et al. 2010) with information primarily obtained from live animal in vivo feed trials and not in vitro experiments. As the relationship between $\mathrm{Cu}$ uptake in the intestine of rainbow trout is well established, we use this metal to probe the comparability of the cell line to the gold standard "gut sac" method already published (for example Nadella et al. 2006b).

In the culture of gill cells, a single seeding technique was initially employed (Parton et al. 1993), but was later adapted to a double seeding technique to improve attachment signals and surface structures (Fletcher et al. 2000). It is now employed as the standard culture method for gill cells (Schnell et al. 2016; Stott et al. 2015). Although a single seeding technique has previously been employed with the RTgutGC cell line (Minghetti et al. 2017, Geppert et al. 2016), we postulate that the application of a double seeding technique with this intestinal model would increase the complexity and therefore efficiency of the model making it more comparable to observations from "gut sac" experiments. A well-established critical step towards the use of in vitro assays as models for in vivo animal experiments is the correlation between in vitro and in vivo activities. In light of the outlined information, our objectives were to investigate the application of the double seeding technique to a fish intestinal cell line (RTgutGC). We hypothesized that an increase in seeding density and double layer of the cells would provide more physiologically relevant intestinal signals and surfaces. This would take the form of polarised microvilli, presence of mucosubstances, tight junction formation, transporters such as p-glycoprotein in addition to other metabolic enzymes. After the thorough characterisation of the model's basic structure, the ability of the RTgutGC cell line to tolerate the application of saline in the apical compartment with minimum adverse effects was investigated. Following the establishment of the intestinal cultures, biological responses following environmentally level of exposures to $\mathrm{Cu}$ was determined in terms of cellular viability, cytotoxicity, genotoxic and gene expression responses in order to probe the robustness of the model.

\section{Materials and methods}

\section{Experimental design}

Experiments were carried out in two stages, with stage I establishing the prerequisite requirements of an intestinal in vitro model (i.e. epithelial growth, mucosubstances, TEER (transepithelial electrical resistance) polarised microvilli). This was followed by stage II in which the evaluation of $\mathrm{Cu}$ uptake by the in vitro intestinal model was performed in order to demonstrate comparability to the wellestablished "gut sac" method. Basic characterisation of the cell line was carried out to determine morphological characteristics, cellular viability, lactate dehydrogenase (LDH) level and genotoxic response (as determined by alkaline single cell electrophoresis or comet assay). Following basic characterisation as mentioned above, in stage II, $\mathrm{Cu}$ uptake by the model was determined using an analytical technique (i.e. ICP-OES) to demonstrate comparability to existing "gut sac" recordings (Nadella et al. 2006b). This was complemented by transcriptional expression analyses of the key genes involved in metal metabolism and stress response using RT-PCR. The selection of $\mathrm{Cu}$ concentration (i.e. 3 and $63 \mu \mathrm{M}$ ) represented non-toxic nominal concentrations typically found in the supernatant or lumen of intestinal compartment (Nadella 2006a, b). In order to make the in vitro model biologically relevant, cells were grown on Transwell inserts with cells seeded in layers (Fig. 1).

This Transwell system allows the growth of a monolayer in the apical compartment, with modifications of the media in both the apical and basolateral compartment possible (Fig. 1). The purpose of this study was to identify how this model compares with "gut sac" preparations. The double layering discussed in later sections was accomplished through seeding one layer initially, allowing cells to attach and grow, and then seeding again with more cells so that the first layer acts as scaffold thereby allowing cells to differentiate fully in a shorter period of time. Until now, this particular system has not been widely used in intestinal human cultures, but has been successfully employed using other cell types such as gills (Schnell et al. 2016, Stott et al. 2015). In addition, the model was tested for the ability to 


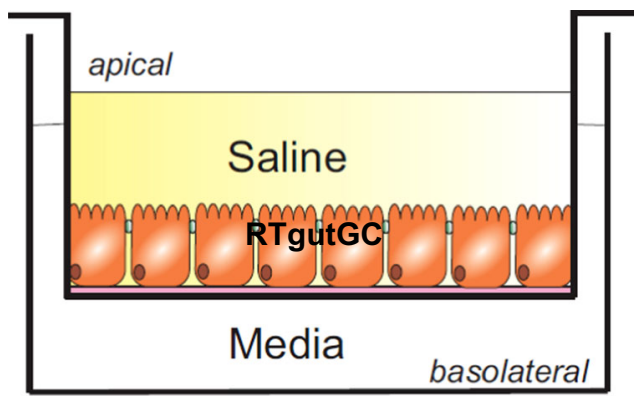

Fig. 1 Outline of a typical single seeded Transwell culture system. The presence of two compartments (i.e. apical and basolateral) allow for the development of additional complexity into in vitro culture systems and exposure to environmental solutions. The system is widely used in human intestinal cultures and has been successfully employed using other cell types and double layers such as fish gills (Schnell et al. 2016, Stott et al. 2015). In the current study, the apical culture medium was substituted with a complex saline solution to investigate the compatibility of the cell line used (i.e. RTgutGC) for the assessment of environmental mixtures in future studies

tolerate complex saline solutions by substituting medium in the apical compartment for this solution. This was investigated to establish whether the cell line would be capable of being used with environmental samples in the future.

\section{Chemicals and reagents}

Leibovitz 15 medium (L-15), Dulbecco's phosphate buffered saline (DPBS), trypsin, versene and Foetal bovine serum (FBS) were purchased in stock batches from ThermoFisher Scientific (UK). Plasticware in the form of T-75 $\mathrm{cm}^{2}$ flasks were exclusively obtained from Greiner Bio One (UK) while Transwell inserts were purchased from VWR (734-0051; Corning, UK). All chemicals were obtained from Sigma unless otherwise stated including Copper sulphate $\left(\mathrm{CuSO}_{4} \cdot 5\right.$ $\mathrm{H}_{2} \mathrm{O}$ ). Prior to the experiment, Cortland saline (Klinck and Wood, 2011) was prepared, $\mathrm{pH}$ adjusted to 7.7 and 7.4 $(\mathrm{HCl})$, filter sterilised, aliquoted into $500 \mathrm{~mL}$ bottles and autoclaved for later use with cell culture. Osmolality of exposure solutions (L-15 and L-15:saline) was 274 mOsm and $204 \mathrm{mOsm}$, respectively, measured via a $5004 \mu$ Osmette micro osmometer (Precision Systems, Massachusetts, USA).

\section{Cell culture}

The rainbow trout gastrointestinal cell line RTgutGC (Kawano et al. 2011) was a kind gift from Dr. Lucy Lee (University of Fraser Valley, Canada). The cell line was routinely cultured in $75 \mathrm{~cm}^{2}$ culture flasks at a seeding density of $5 \times 10^{4}$ cells $/ \mathrm{mL}$ in an incubator set at $21^{\circ} \mathrm{C}$ in L-15 culture medium supplemented with $10 \%$ FBS as per Kawano et al. (2011). All experiments were carried out in a controlled incubator set to $21^{\circ} \mathrm{C}$ with non-parallel passages
(17-37). A passage cut off of 37 was employed due to deviation from normal growth morphology. During this study, higher seeding densities than previously employed with the RTgutGC cell line were used. Both Minghetti et al. (2017) and Geppert et al. (2016) reported using 62,500 cells per $\mathrm{cm}^{2}$ under single seeding conditions (grown for 21 days) while our study employed $89-179,000$ cells per $\mathrm{cm}^{2}$ (grown for 5 days) dependent on single or double seeding methodology. Kawano et al. (2011) previously observed that under super confluent conditions, RTgutGC cells stain intensely for alkaline phosphatase (an indicator of cellular differentiation) suggesting that high seeding densities may affect the structural and functional properties of the intestinal monolayer. This trend has previously been observed in the Caco-2 cell line (Natoli et al. 2011), where it is typically grown for 21 days to allow full differentiation.

Prior to $\mathrm{Cu}$ exposure experiments, cells were first grown both single seeded and double seeded on Transwell inserts to identify the variability between models over a short time period (9 days) (Fig. 1). Cells were seeded at a density of $1 \times 10^{5}$ cells per $\mathrm{mL}$ of conditioned media for single seeding. With respect to double seeding, cells were again seeded at a density of $1 \times 10^{5}$ cells $/ \mathrm{mL}(\sim 89,285$ cells per $\mathrm{cm}^{2}$ ) and allowed to attach for $24 \mathrm{~h}$. After $24 \mathrm{~h}, 500 \mu \mathrm{L}$ of the media in the apical compartment was replaced with secondary flask (same passage) at a seeding density of $2 \times$ $10^{5}$ cells $/ \mathrm{mL}$, giving a final seeding density of $2 \times 10^{5}$ cells $\left(178,571\right.$ cells per $\left.\mathrm{cm}^{2}\right)$ in $1 \mathrm{~mL}$ of cell culture media. Cells were grown for 9 days initially to identify stabilisation of TEER measurements, with medium changes to both apical and basolateral media performed every $48 \mathrm{~h}$.

\section{Morphological characterisation}

RTgutGC cells grown on Transwell inserts for 5-7 days were fixed with $4 \%$ formol saline for $1 \mathrm{~h}$, and stained with periodic acid and alcian blue to assess presence of mucosubstances. To stain for tight junctions, cells were grown as monolayers on coverslips and processed as normal as previous studies have shown no difference in immunofluoresence staining of cells on coverslips vs. Transwell systems (Gillespie et al. 2016). The tight-junction protein zonula occludens 1 (ZO-1) and E-cadherin (E-Cad) were detected using polyclonal antibodies goat anti-mouse (1579585; ThermoFisher) and goat anti-rabbit (1583138: ThermoFisher) as per Gendron et al. (2011). The secondary antibodies used were Alexa Fluor 594 (10644773; Fisher Scientific, UK) and Alexa Fluor 488 (10729174; Fisher Scientific, UK) at a concentration of $10 \mu \mathrm{g} / \mathrm{mL}$. Cells were counter stained with DAPI to stain nuclei. Images were obtained using a Nikon epifluoresence microscope (Eclipse 80i) with camera attachment (DS-Qi1Mc). Images were captured and processed using the NIS elements application 
suite (Nikon). Finally, double seeded cells were allowed to grow until confluent (7-9 days) on a Transwell insert and fixed in $2.5 \%$ glutaraldehyde (in $0.1 \mathrm{M}$ sodium cacodylate buffer; $\mathrm{pH}$ 7.2). Cells were washed with buffer $(0.1 \mathrm{M}$ sodium cacodylate; $\mathrm{pH}$ 7.2) and then secondary fixed with Osmium Tetroxide (1 h). After buffer washes, samples were dehydrated through grades of ethanol, and resin embedded (in Agar low viscosity resin). The resulting block was sectioned with a Leica Ultracut $\mathrm{E}$ ultramicrotome using a Diatome diamond knife (Agar Scientific; Stanstead UK), with sections ( $80 \mathrm{~nm}$ thick) transferred to a $200 \mu \mathrm{m}$ mesh thin bar copper grids (Agar Scientific, UK). Sections were stained with uranyl acetate and Reynolds lead citrate and images captured on a JEOL 1400 TEM using a variety of magnifications. An accelerating voltage of $120 \mathrm{kV}$ was used to capture images using a Gatan Orius camera.

\section{Transepithelial electrical resistance (TEER)}

As single seeding of RTgutGC cells has previously been carried out (Geppert et al. 2016), we first established the comparability of single (SSI) and double seeding (DSI) using TEER and chopstick electrodes. Cells were seeded onto a permeable polyethylene (PET) membrane inserts with $0.4 \mu \mathrm{m}$ pores with a surface growth area of $1.13 \mathrm{~cm}^{2}$ (Corning, UK) and maintained at $21^{\circ} \mathrm{C}$. The development of an intact intestinal epithelium was monitored daily through blank-corrected measurements of TEER using an EVOM epithelial voltohm-meter (World Precision Instruments, Hertfordshire, UK) fitted with chopstick electrodes (STX-2). As discussed in Results, TEER, with culture medium on both surfaces, increased minimally in both the SSI and DSI preparations, both reaching a stable plateau at approximately 6-9 days. Following the identification of a similar trend between the two models, the double seeded technique was hence employed in the following experiments, with exposures carried out from day 5 (Cu dosing).

As discussed in Results, Low TEER values suggested that the RTgutGC cell line may represent a "leaky gut" environment where resistance measurements may be very small. Indeed, the presence of variability between the methods outlined above would suggest the need for a more sensitive tool to measure TEER. To optimise the reliability of TEER measurements, dosing experiments used the more sensitive Endholm 12 culture cup, which is designed for epithelium with low TEER values. Experimental cultures were established as outlined below in section Experimental conditions. Appropriate blank corrections were determined for each experiment and for each TEER recording from inserts with no cells and incubated with appropriate apical (saline or L-15) and basolateral solutions identical to those used in experimental preparations (L-15 with minimal FBS). All experiments and exposures were based on 2-3 inserts derived from one biological replicate equivalent to one passage of the RTgutGC cells. Results are representative of three experiments with TEER values given as $\Omega \mathrm{cm}^{2}$.

\section{Experimental conditions}

Prior to experiment, cell viability was assessed using the trypan blue cell exclusion assay, with a viability of $>98 \%$ deemed appropriate for future experimentation. Cells were seeded as outlined in previous sections and media exchanged after $48 \mathrm{~h}$ (full basolateral and half apical). A half media exchange (unconditioned L-15 medium) was carried out on day 4 of cell growth (apical and basolateral). In preliminary work carried out prior to the experiment, the cell line was found to be able to tolerate apical saline for a period of $24 \mathrm{~h}$, but at a ratio of 1:1 (L-15:saline) is capable of tolerating it for a period of $96 \mathrm{~h}$ without adverse effects in terms of cell viability or LDH [data not included]. Due to this capacity, the experimental design allowed for probing the modification of the $\mathrm{pH}$ of the apical media to physiologically relevant ranges (i.e. $\mathrm{pH} 7.7$ and 7.4). This $\mathrm{pH}$ range relates to the mid and posterior intestinal regions respectively (Fard et al. 2007) which could modify the cell line behaviour in terms of uptake and other biological responses to a more region specific response. Hence, on day of exposure $500 \mu \mathrm{L}$ of medium was removed from all apical compartments, and exchanged for $500 \mu \mathrm{L}$ of controls (unconditioned L-15:saline $\mathrm{pH}$ 7.7/7.4) or $\mathrm{Cu}$ consisting of the control solution spiked with 6 and $126 \mu \mathrm{M}$. Stock concentrations of $\mathrm{Cu}$ (in DPBS) were made prior to the experiment, with experimental concentrations measured prior to each experiment by inductively coupled plasma mass spectrometry (ICP-OES; iCAP 7000 Series ICP spectrometer, Thermo Scientific, USA) with $\mathrm{Cu}$ standards from ThermoFisher (UK). All biological responses (i.e. LDH measurements, genotoxic response, $\mathrm{Cu}$ uptake and gene expression) were carried out on Transwell inserts under double seeding conditions except for quantification of tight junction formation and cell viability, which were grown as single seeded monolayers. Characterisation of response of cells to $\mathrm{Cu}$ began with exposure on day 5, with the first sample recorded on day 6 (i.e. after $24 \mathrm{~h}$ or day 1 of exposure) and thereafter every 24 $\mathrm{h}$ for the duration of the experiment. To aid in comparisons to literature, the exposure conditions will henceforth be referred to in hours $(24,48,72 \mathrm{~h})$ to denote time elapsed post exposure and avoid confusion with period of time to culture.

\section{Analysis of biochemical and genotoxic responses}

\section{Determination of cell viability}

Cell viability was assessed using the acid phosphatase assay (APH) as per the methodology of Friedrich et al. (2007, 
2009). Cells were seeded in 96 well plates at similar seeding densities to the double seeded insert model (scaled for volume difference between plastic-ware) and allowed to grow for 5 days prior to exposure. This is equivalent to a seeding density of 40,000 cells per well of a 96 well plate (200 $\mu \mathrm{L}$ volume). Cells were exposed as outlined in Experimental conditions, washed with Dulbecco's phosphate buffered saline (DPBS) prior to the addition of Acid phosphatase buffer (APH) containing $0.1 \mathrm{M}$ sodium acetate, $0.1 \%$ Triton X-100 supplemented with $p$-nitrophenyl and incubated for $4 \mathrm{~h}$ at $21{ }^{\circ} \mathrm{C}$ in the dark. Following incubation, $10 \mu \mathrm{L}$ of $\mathrm{NaOH}$ was added to each well to stop the reaction and absorbance measured on a spectrophotometer (FLUOstar Omega, BMG Labtech, UK) at $405 \mathrm{~nm}$. Data was expressed as a percentage of control (unexposed cells in L-15 media) after correction for fluorescence from incubation buffer.

\section{Determination of lactate dehydrogenase $(\mathrm{LDH})$ activity}

Concurrent to the collection of media from apical compartment of cells grown on Transwell inserts for analysis of $\mathrm{Cu}$ uptake, $200 \mu \mathrm{L}$ of exposure medium was collected from surplus fluid at each sampling time and analysed for extracellular stress using the LDH assay as per Scholz and Segner (1999). Briefly, $50 \mu \mathrm{L}$ of the media/saline aliquot was added to each well of a 96-well micro-plate in triplicate on ice and incubated with $250 \mu \mathrm{L}$ of reaction buffer (50 mM TRIS/HCL, $0.14 \mathrm{mM} \mathrm{NADH;} \mathrm{pH} 7.5$ ) for $5 \mathrm{~min}$ at room temperature. Following incubation, the reaction started with the addition of $25 \mu \mathrm{L}$ of $12.1 \mathrm{mM}$ sodium pyruvate dissolved in $50 \mathrm{mM}$ TRIS/HCL buffer $(\mathrm{pH}$ 7.5). Plates were briefly mixed and the enzyme activity recorded for $20 \mathrm{~min}$ at $25^{\circ} \mathrm{C}$ in a micro-plate reader (FLUOstar Omega, BMG Labtech, UK) at $340 \mathrm{~nm}$. Enzyme expression was subsequently standardised to cell counts.

\section{Determination of genotoxic response}

Genotoxic response following $\mathrm{Cu}$ exposure was assessed using single gel electrophoresis or comet assay and performed as per previously described for fish cell lines (Papis et al. 2011, Reeves et al. 2008, Nehls and Segner 2005, Raisuddin and Jha 2004). Prior to $\mathrm{Cu}$ exposure, the assay was validated using hydrogen peroxide as a reference genotoxic agent [data not included]. Briefly, cells were cultured as normal for 5 days and exposed to $\mathrm{Cu}$ as outlined previously.

Cells were removed from the wells using trypsin, with cell viability assessed using the Trypan Blue exclusion assay revealing an average viability of $97-98 \%$ (data not included). A subset of this cellular suspension was re- suspended in $1.5 \%$ normal melting point agarose, covered with a coverslip and dried at $4{ }^{\circ} \mathrm{C}$. Slides were immersed in lysis solution for $1 \mathrm{~h}$ and then placed in electrophoresis tank to unwind (Compac-50 HTP Comet Assay Tank, Cleaver Scientific, UK). Electrophoresis was performed at $25 \mathrm{~V}$, $620 \mathrm{~mA}$ for $25 \mathrm{~min}$. Sliders were scored using an epifluoresence microscope (DMR; Leica Mi- crosystems, Milton Keynes, UK) and imaging system (Comet IV, Perceptive Imaging, UK) where 50 cells per microgel (100 cells per slide) were analysed per treatment. Slides were coded and randomised to ensure unbiased scoring. Comet assay software packages record a number of different parameters, with \% tail DNA considered the most reliable (Kumaravel and Jha, 2006). Hence, comet assay results are reported as \% tail DNA.

\section{Copper uptake using ICP-OES}

For analysis of $\mathrm{Cu}$ uptake in the Transwell intestinal system, the experimental design consisted of three concentrations in the apical compartment of the Transwell system (L-15: saline control, 3 and $63 \mu \mathrm{M}$ ) over a $72 \mathrm{~h}$ period. Exposure concentrations chosen represent nominal concentrations of $\mathrm{Cu}$ found in the supernatant of gut contents and have been associated with reported standard fish farm diets between 5-70 $\mu \mathrm{ML}^{-1}$ (Nadella et al. 2006b), though these concentrations are dependent on the region of the gut sampled (Ojo and Wood et al. 2007). Medium was removed from the apical $(1 \mathrm{~mL})$ and basal $(2 \mathrm{~mL})$ compartment of the insert and analysed separately to account for active transport of the $\mathrm{Cu}$ between the apical and basal compartment (24-72 h). Duplicate samples were analysed with calibration, reagent blanks and reference material $(\mathrm{Cu})$ to check quality assurance and quality control at the beginning, during and at the end of each ICP-OES run. For each model, biological variability was incorporated by repeating the experiment in non-parallel passages, so henceforth all results presented are indicative of an $n$ of 4 (passages 24-37). The accumulation/ loss of $\mathrm{Cu}$ was analysed among the treatment concentrations $(0,3$ and $63 \mu \mathrm{M})$, time and between exposure solution conditions ( $\mathrm{pH} 7.7 / 7.4)$.

\section{Copper $(\mathrm{Cu})$ uptake analysis}

$\mathrm{Cu}$ uptake ( $\mathrm{nmol} \mathrm{cm} \mathrm{cm}^{-2} \mathrm{~h}^{-1}$ ) was calculated based on Klinck and Wood (2011) with some small modifications. The uptake rate has been modified to represent

$$
\text { Jin }=c p m \times(S A \times t \times G S A)^{-1}
$$

Where, cpm now represents final concentration in ppm, SA represents the initial measurements (initial exposure taken from stock reagents), $\mathrm{t}$ is the flux time (how long they were exposed; 24,48 and $72 \mathrm{~h}$ ) and GSA is the insert 
surface in $\mathrm{cm}^{2}$. Uptake rate was based on supernatant collection from the apical compartment during exposure experiment and standardised to surface area of Transwell cup where a larger $\mathrm{Cu}$ concentration at the end would indicate reduced $\mathrm{Cu}$ metabolism in the model. Data was tested for assumptions and analysed using analysis of variance (ANOVA) with exposure concentrations, time course and $\mathrm{pH}$ of exposure solution as the main factors.

\section{RNA extraction and reverse transcription}

Due to $3 \mu \mathrm{M} \mathrm{Cu}$ representing environmental background levels in aquatic systems, this concentration was used as the negative control in this experimental part. Total RNA was isolated from pooled Transwell samples (3) of double seeded RTgutGC cells using RNAzol RT (R4533; Sigma, Germany). RNA quality was assessed using a Nanodrop ND1000 (ThermoFisher, UK), and RNA concentration quantified using a fluorescence kit (Quant-iT RiboGreen; Life Technologies, UK) according to manufacturer's instructions. Twenty nanograms of samples with $\mathrm{OD}_{260}$ : $\mathrm{OD}_{280}>1.9$ and crisp bands were used for reverse transcription with NanoScript2 Reverse Transcription kit with Oligo-dT primer and random nonamer primers (RT-nanoScript2; PrimerDesign, UK). RT-PCR was performed on samples in triplicate (Step-One Plus RT-PCR system, Applied Biosystems) on a 384 plate with reactions containing $5 \mu \mathrm{L}$ of Syber Green, forward and reverse primers (supplementary information), reference dye and nuclease free water to a final volume of $10 \mu \mathrm{L}$ per well and $2 \mu \mathrm{L}$ template cDNA. Initial denaturation was $94^{\circ} \mathrm{C}$ for $2 \mathrm{~min}$, followed by 40 cycles of $94{ }^{\circ} \mathrm{C}$ for $15 \mathrm{sec}$ and $60^{\circ} \mathrm{C}$ for 1 min, with a melt curve to verify PCR-product purity. RTcontrols and appropriate no-template controls were also run using sterile nuclease free water.

\section{RT-qPCR}

Primer concentration was optimised prior to experimentation to improve performance of RT-PCR as suggested by manufacturer (Table S1). Relative expression ratio (RER) of 5 genes selected for the study (i.e. CYP3A, $m t A, S O D, G S T$ and $P g p$ ) was calculated relative to a pseudo reference gene composed of $\beta$-actin, efl $\alpha$ (elongation factor $1 \alpha$ ) and $18 \mathrm{~s}$ as per recommendations by Vandesompele et al. (2002) to mitigate relatively large errors while using a single reference gene. Amplification efficiencies of individual reactions were incorporated as per recommendations by $\mathrm{Liu}$ and $\mathrm{Hu}$ (2002), with PCR efficiency measured using LinRegPCR (Ramakers et al. 2003) relative to a"pseudo-housekeeper". Data was analysed using the efficiency corrected method of Pfaffl (2001), with individual sample efficiency (calculated using LinReg) as has been applied in other RT-PCR analysis methods (Rao et al. 2013). Statistical analysis of gene expression data was carried out using the non-parametric Wilcoxon Rank Sum test on $\Delta \mathrm{Ct}$ value $\left(\mathrm{Ct}_{\text {target }}-\mathrm{Ct}_{\text {reference }}\right)$ as recommended by Yuan et al. (2006). This test was chosen due to its robustness with small sample sizes and lack of presumption regarding data distribution.

\section{Statistical analysis}

Statistical analyses were performed in R Version 3.1.3 (RStudio T 2015). Data is given as the mean value \pm standard error of the mean (SEM), with "n" denoting replicates (passages) per experiment. These replicates are representative of non-parallel passages of the RTgutGC cell line, with each recording representing of 2-4 technical replicates. All data was first tested for normality using the AndersonDarling Normality test (AD) in addition to examination of QQ-plots, while homogeneity of variance was conducted using Levene's test, and an appropriate parametric or nonparametric test was then applied. Data which did not meet the assumptions of normality for parametric tests were analysed using the Kruskal-Wallis test followed by Dunn's pairwise posthoc test with Bonferroni correction. In addition to analysis of Relative expression ratio, correlations between gene's were determined using Pearson's correlation co-efficient. Due to the multiple factors, data was analysed using a 2-way ANOVA with Tukey's pairwise comparisons as post hoc if test assumptions were met. As per Dallas et al. (2013), median values of \% tail DNA were used for statistical analysis. For all statistical analyses, a value of $p<$ 0.05 was considered significant.

\section{Results}

\section{Morphological characterisation}

The RTgutGC cells demonstrated typical epithelial morphology when grown as a single monolayer (Fig. 2a). Histological staining of the double-seeded monolayer revealed weak staining of neutral mucosubstances indicative of mucus secretion by the epithelial cells (Fig. 2b). Additionally, cells consistently (in both single and double seeded form) expressed the tight junction protein Z0-1 and E-cadherin supporting the identification of these cells as epithelial in nature (Fig. 2c). Examination of the ultrastructure of the double seeded cells revealed a polarised monolayer of cells grown for 5-7 days on Transwell supports (Fig. 2d). The untreated cells exhibit basally located nuclei and apical microvilli (Fig. 2d). These layers are rich in mitochondria, rough endoplasmic reticulum and tight junctions. The microvilli protrusions on the apical side of 

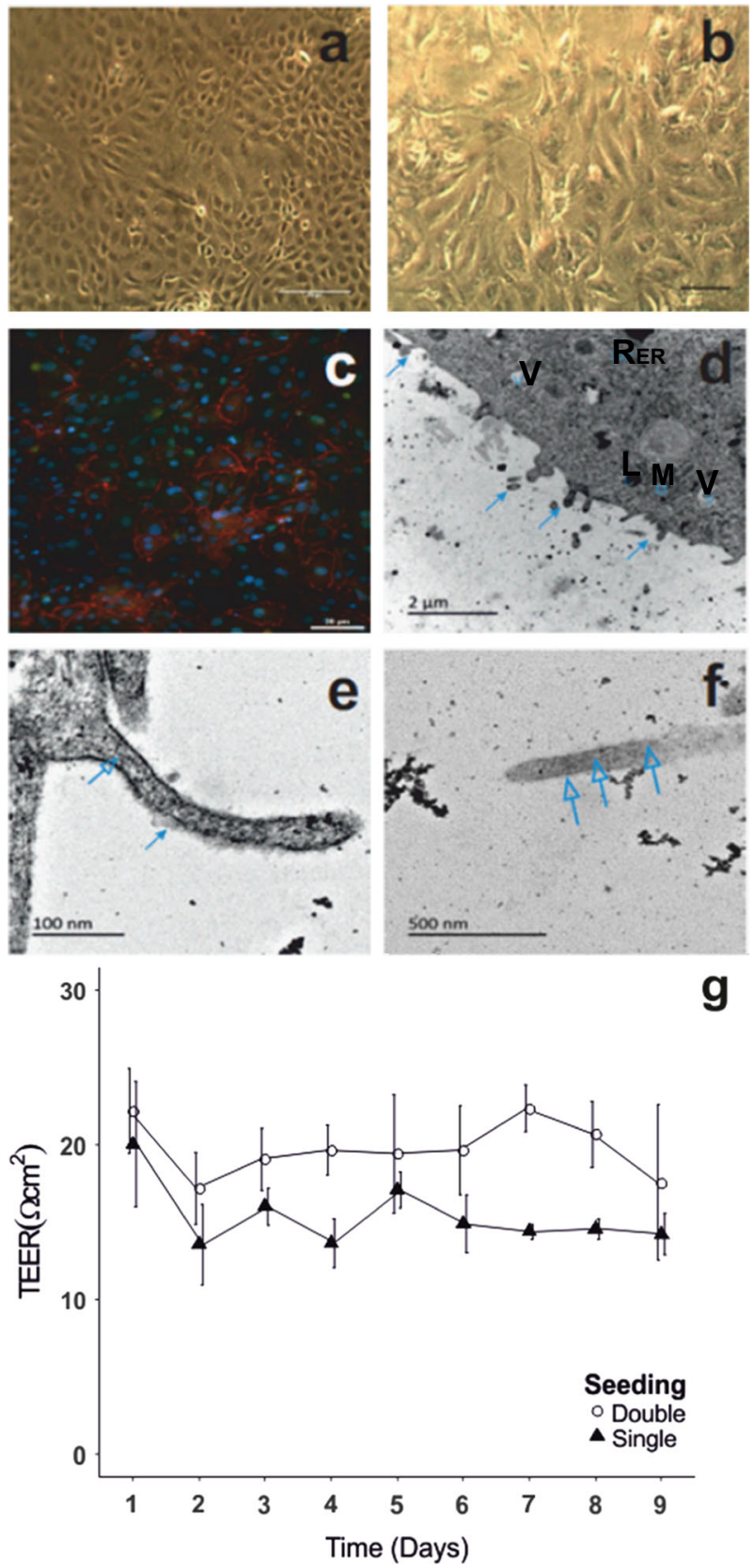

g

the membrane have been verified through the identification of a fibrillary coat or glycocalyx on the outside of the structures identified as microvilli and which were present even under saline exposure conditions (Fig. 2e). In addition, as support of these structures as microvilli, the filamentous cytoskeleton of the microvilli was observed extending into the monolayer cytoplasm (Fig. 2f). Cells developed a transepithelial electrical resistance (TEER) of $14 \pm 1.33 \Omega$ $\mathrm{cm}^{2}$ and $17 \pm 5.02$ for single and double seeded cells over 9 days respectively, with no significant difference observed in either model over time $(n=4, p>0.05)$ (Fig. $2 \mathrm{~g})$.
Fig. 2 Characterisation of the double seeded intestinal fish cell model under in vitro conditions. a Characteristic epithelial growth of the RTgutGC cells after 7 days in single layer culture. b Double seeded RTgutGC cells grown on Transwell inserts showing weak positive staining for neutral mucosubstances indicative of active mucous secretion. c Immunofluoresence staining for ZO-1 (red) and Ecadherin (green) of double seeded RTgtuGC cells grown on Transwell inserts. Nuclei were counter stained with DAPI (blue). As expected, ZO-1 is expressed predominantly on the periphery of cells, while Ecaderin is localised to the cell surface. $\mathbf{d}-\mathbf{f}$ : Sub-cellular characterisation of double seeded RTgutGC cells confirms the presence of $\mathbf{d}$ polarised cells with microvilli protrusions [closed arrow heads]; Abbreviations: $\operatorname{Rer}$ rough endoplasmic reticulum, $M$ mitochondria, $L$ lysosomes, $V$ vesicles and $\mathbf{e}$ fibrillary coats surrounding the protrusions [closed arrow head]; f Further confirmation of microvilli through the presence of a filamentous cytoskeleton running the length of the structure [open arrow head]. $\mathrm{g}$ Transepithelial electrical resistance (TEER) of RTgutGC cells seeded under double and single seeding conditions with no significant difference observed over time $(p>0.05)$ as measured using chopstick electrodes

\section{TEER}

The replacement of the chopstick electrodes with the use of the static Endholm chamber resulted in an increase in baseline TEER measurements (Fig. 3a). However, the previously observed trend of a plateau in TEER following 6-9 days (Fig. 2g) was also observed using this method. As cells integrated following the double seeding event (initial seeding denoted as day 0 , secondary seeding day 1 ), TEER resistance increased by approximately $\sim 40 \%$ from 126.24 $\pm 2.96 \Omega \mathrm{cm}^{2}$ to $212.7 \pm 37.6 \Omega \mathrm{cm}^{2}(n=9)$ (Fig. 3a). Analysis of the data revealed non-normal data, with unequal variance. Significant differences were observed over time $(p<0.05$, Kruskal-Wallis) with Dunn's posthoc test revealing significant differences between day 3 and day 6 only ( $p<0.05$, Dunn's test) (Fig. 3a). A direct comparison of TEER between medium $(\mathrm{pH} 7.5)$ and medium:saline $(\mathrm{pH}$ $7.7 / \mathrm{pH} 7.4$ ) revealed an increase from $21.16 \pm 0.68 \Omega \mathrm{cm}^{2}$ in L-15 alone to an average of $26.19 \pm 4.77 \Omega \mathrm{cm}^{2}$ in saline on day 5 of sampling. This trend in increased TEER in medium:saline solutions vs. medium on its own is repeated when $\mathrm{Cu}$ exposures are also incorporated. No significant difference in TEER was observed during the exposure time of 6-9 days in L-15 alone (Fig. 3a), in the saline:medium combination (Fig. 3b), or in any combination of $\mathrm{pH}$, concentration or sampling time.

\section{Analysis of biochemical and genotoxic response}

\section{Cell viability}

In addition to preliminary screening of cellular viability using the Trypan Blue exclusion assay, three experiments were performed to analyze for variation in cellular viability 

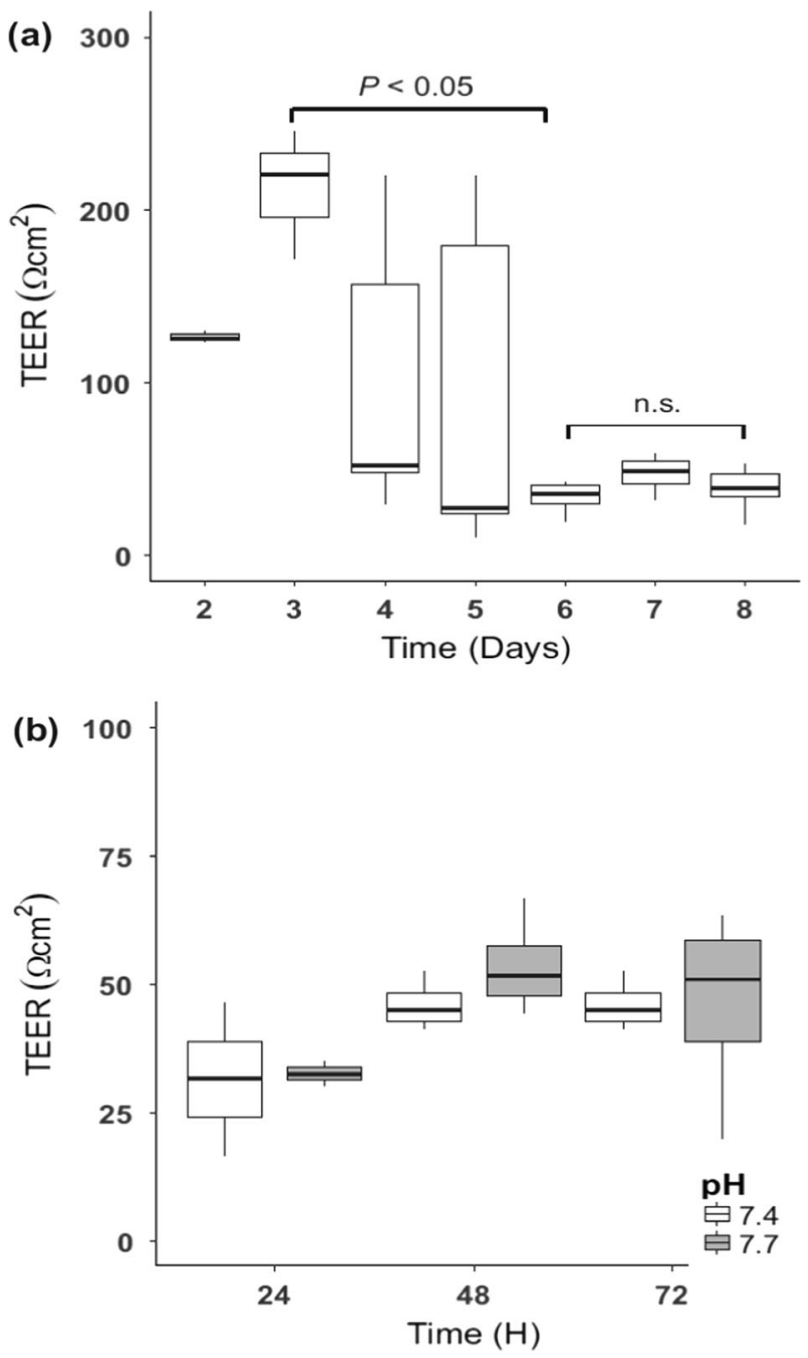

Fig. 3 a Transepithelial electrical resistance (TEER) of the double seeded RTgutGC cell line over a 8 day period under symmetrical conditions (L-15 medium and 10\% FBS in both apical and basolateral compartments) measured using the Endholm 12 culture cup system. Significant differences were only observed between day 3 and day 6 , but not during the experimental time period (day 6-8). b Asymmetrical conditions where saline was applied to the apical compartment at a 1:1 ratio (L-15 medium: saline) and L-15 medium (containing FBS) was maintained as normal in the basolateral compartment. The application of saline to the apical compartment reveals a comparable trend in increased resistance (TEER) over time with a stabilisation after $72 \mathrm{~h}$. This trend of stabilisation of TEER was also observed in L-15 medium (a) however no significant difference was observed between saline exposures (b). Significance was set at $p>0.05$

using the APH assay following the multi-factor $\mathrm{Cu}$ exposure which took into account the confounding factors (e.g. $\mathrm{pH}, \mathrm{Cu}$ concentrations and exposure time). The results of the cell viability assay were presented as percentage of the control following media autofluorescence blank correction (L-15 media with no exposure) and were logit transformed. Application of Anderson Darling normality test revealed normal data $(n=3, p>0.05)$, with homogeneous distribution (QQ-plot). A two-way ANOVA revealed no significant differences between concentrations $(p=0.27)$ or $\mathrm{pH} \quad(p=0.92)$. Nonetheless, significant differences were observed between time which was consistent between assays $(p<0.001)$, with Tukey's posthoc test identifying differences between 24 and $48 \mathrm{~h}$ cell viability $(p<0.001)$ and 48 and $72 \mathrm{~h}$ exposure $(p<0.001)$ (Fig. 4a, b).

\section{Lactate dehydrogenase (LDH) activity}

Four experiments were performed to determine damage to the cellular membrane following $\mathrm{Cu}$ exposure. Data was analysed using a Kruskal Wallis test due to non-normal data with unequal variances and found no significant differences between any of the factors (time, $\mathrm{Cu}$ concentration or $\mathrm{pH}$ ). The data is presented was Fig. $4 \mathrm{c}, \mathrm{d}$ as the release of LDH into the media corrected by cell count.

\section{Genotoxic response}

Three experiments were performed to determine genotoxic response to $\mathrm{Cu}$ using our multi factor experimental design. Mean \% tail DNA was used in analysis due to its normal distribution ( $p=0.20 \mathrm{AD}$ test). As noted in previous assays, no genotoxic response was found following $\mathrm{Cu}$ exposure. However, significant differences were identified over time $(p<0.001)$ with Tukey's post hoc test identifying differences in response between 24 and $72 \mathrm{~h}(p<0.001)$ and 48 and $72 \mathrm{~h}(p<0.001)$ respectively (Fig. $4 \mathrm{e}, \mathrm{f})$, a trend also observed in the cell viability assay.

\section{Copper uptake}

Four experiments $(n=4)$ were performed to determine difference in $\mathrm{Cu}$ uptake rate dependent on $\mathrm{pH}$ of exposure solution in apical compartment of Transwell system. All samples used for $\mathrm{Cu}$ uptake had a baseline TEER value of $>20 \Omega \mathrm{cm}^{2}$. Background concentrations of $\mathrm{Cu}$ in the Cortland saline solution at both $\mathrm{pH} 7.7$ and $\mathrm{pH} 7.4$ were 0.0468 $\pm 0.0022 \mathrm{ppm}(0.73 \pm 0.03 \mu \mathrm{M})$ and $0.01198 \pm 0.00647$ ppm $(0.19 \pm 0.10 \mu \mathrm{M}) \mathrm{Cu}$ respectively prior to exposure. Analysis of the data revealed non-normal data, with unequal variance. Significant differences were observed over time for both $3 \mu \mathrm{M}$ ( $\mathrm{p}<0.001$, Kruskal-Wallis) and $63 \mu \mathrm{M}$ (p $<$ 0.001, Kruskal-Wallis). Dunn's posthoc test revealed significant differences between 24 and $72 \mathrm{~h}$ at $3 \mu \mathrm{M} \mathrm{Cu}$ exposure ( $\mathrm{p}<0.001$, Kruskal-Wallis) (Fig. 5a), while significant differences were also observed between 48 and $72 \mathrm{~h}$ ( $\mathrm{p}<0.05$, Kruskal-Wallis) for the $63 \mu \mathrm{M} \mathrm{Cu}$ exposure (Fig. $5 \mathrm{~b})$. A clear trend in response was visible at both concentrations, with the lower $\mathrm{Cu}$ concentration demonstrating 

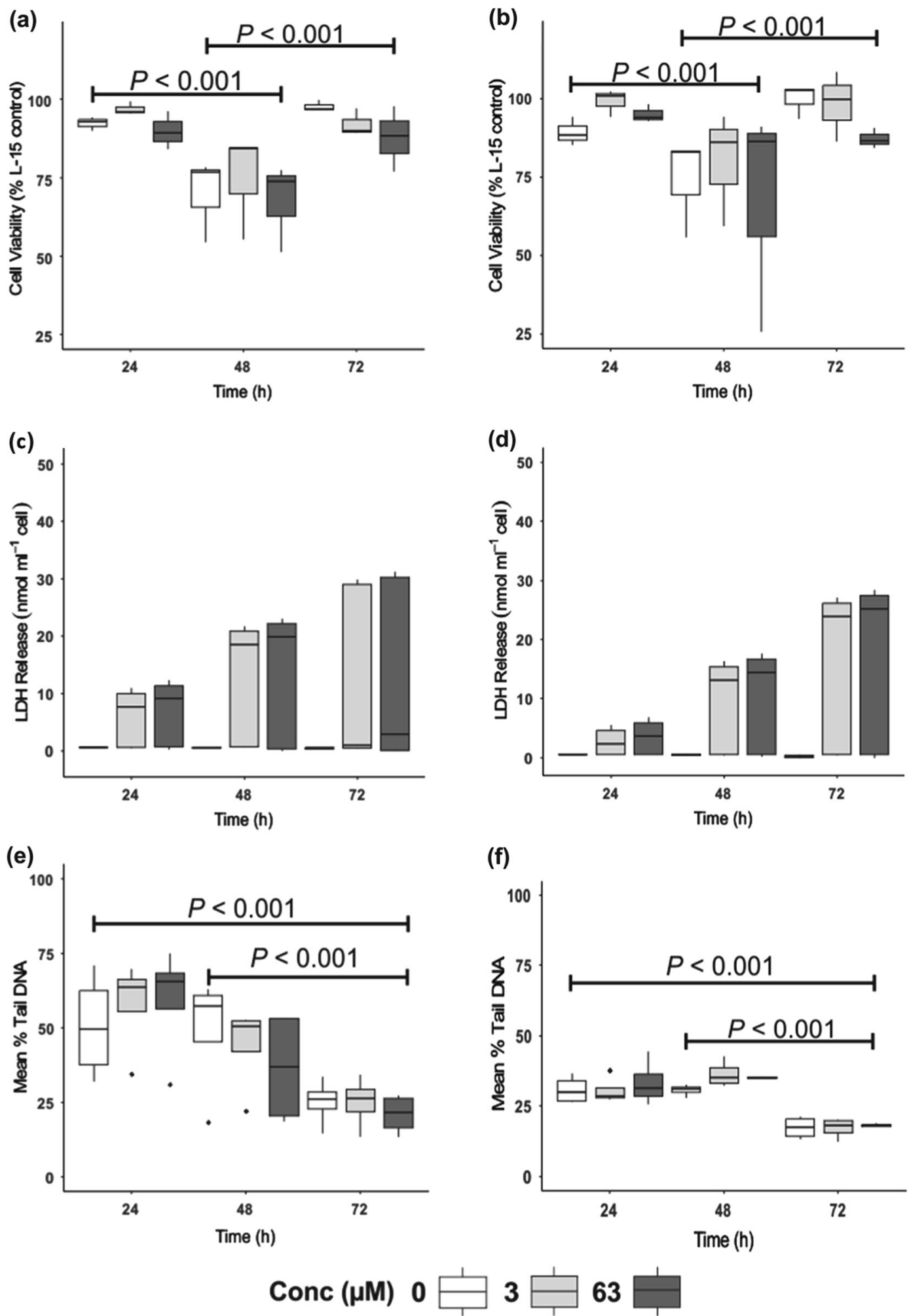

Fig. 4 Comparison of changes in cell viability (APH) (a \& b), LDH (extra-cellular) (c \& d) and induced genotoxic damage (e \& f) following a combined saline/ $\mathrm{Cu}$ exposure. The legends located at the bottom of the graph denotes the $\mathrm{Cu}$ concentration levels, with the first graph of every assay representing $\mathrm{pH} 7.7$ (equivalent to mid intestine)

and the second corresponding graph representing $\mathrm{pH} 7.4$ (equivalent to posterior intestine). Values are presented as the mean \pm SEM, $n=3-4$ biological replicates (passages) with 4 technical replicates per result. Significance was set at $p<0.05$ 


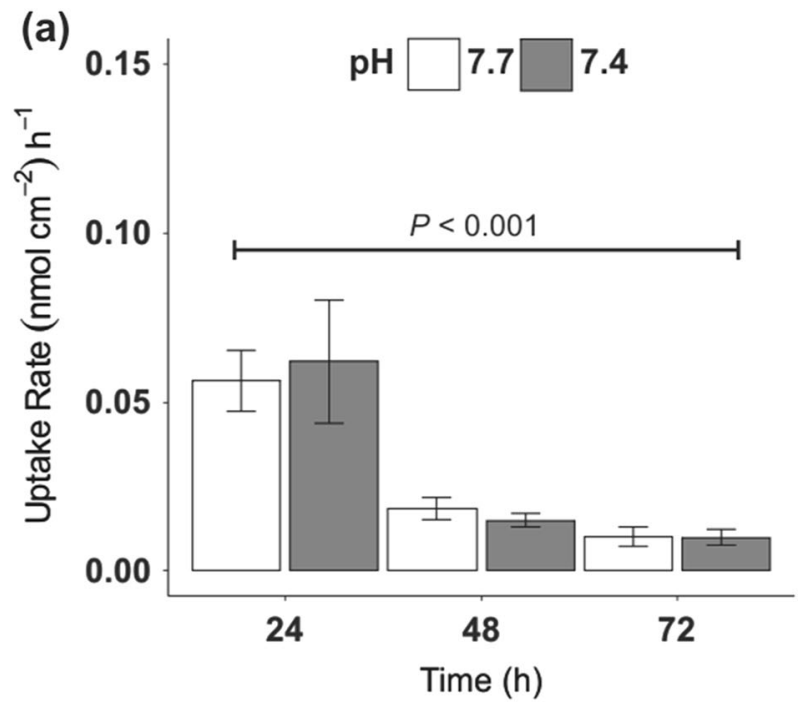

(b)

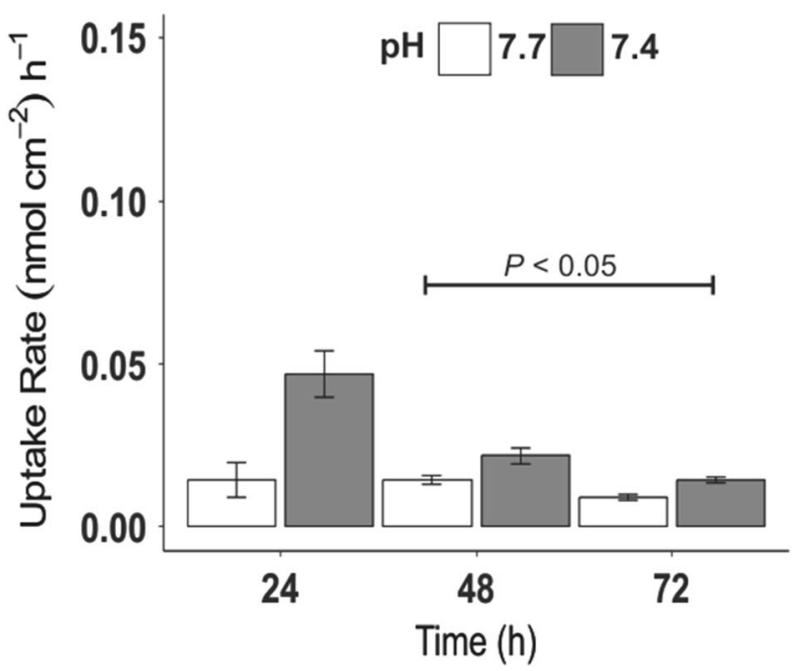

Fig. 5 Copper $(\mathrm{Cu})$ uptake rates in RTgutGC cell line double seeded on Transwell inserts. Robustness of the model was assessed through the application of $\mathrm{Cu}$ in the apical compartment at a 1:1 ratio of L-15 medium to saline at $\mathrm{pH} 7.7$ (white) and 7.4 (grey). Data presented as mean \pm SD over a $72 \mathrm{~h}$ sampling period. Statistical significance was tested using the Kruskal-Wallis test with Dunn's test ran as posthoc. Significant differences found in $\mathrm{Cu}$ uptake between 24 and $72 \mathrm{~h}$ at 3 $\mu \mathrm{M}$ (a) and between 48 and $72 \mathrm{~h}$ following $63 \mu \mathrm{M}$ (b) exposure. However, no significant difference was found between the two $\mathrm{pH}$ levels

a clear $\mathrm{pH}$ paired response. However, at the higher $\mathrm{Cu}$ concentration, the higher $\mathrm{pH}$ (7.7), representative of mid intestinal $\mathrm{pH}$, clearly reached a plateau of uptake with limited difference in response over time (Fig. 5a). In contrast, the lower $\mathrm{pH}$ (7.4), representative of posterior intestinal $\mathrm{pH}$ demonstrated a comparable trend to observations at the lower $\mathrm{Cu}$ concentration (Fig. 5b). This trend in $\mathrm{Cu}$ dependent uptake reiterates the functional properties of this model and reflects previous "gut sac" observations.
Table 1 Pearson's correlation coefficient of the expression of five stress related genes investigated in the study following exposure to $\mathrm{Cu}$ in the RTgutGC cell line

\begin{tabular}{llllll}
\hline & CYP3A & GST & mtA & Pgp & SOD \\
\hline CYP3A & 1 & $0.91^{*}$ & $0.97^{*}$ & $0.95^{*}$ & $0.95^{*}$ \\
GST & - & 1 & $0.87^{*}$ & $0.88^{*}$ & $0.84^{*}$ \\
$m t A$ & - & - & 1 & $0.98^{*}$ & $0.97^{*}$ \\
Pgp & - & - & - & 1 & $0.95^{*}$ \\
SOD & & - & - & - & 1 \\
\hline
\end{tabular}

Strong positive correlations were found in all combinations of genes. Astrix (*) denotes a $p<0.05$

\section{RT-qPCR}

The efficiency of RT-qPCR primers varied with individual samples. This was accounted for during analysis but typically ranged from $80-90 \%$ as assessed by the LinReg programme. The expression of five genes related to xenobiotic defence, metal and oxidative stress were investigated in the Transwell model under two apical $\mathrm{pH}$ exposure scenarios. Analysis of data revealed no significant difference between $\mathrm{pH}$ or as a function of time $(p>0.05)$. Pearson's correlation analysis of gene expression on $\Delta \mathrm{Ct}$ values showed significant positive relationships between analysed genes as presented in Table 1 .

\section{Discussion}

Whilst studies have been carried out to determine the toxicity of metals to intestinal tissue ex situ using"gut sac" methodology (Nadella et al. 2006b, 2007, 2011; Leonard et al. 2009; Ojo and Wood et al. 2007), there is little information on the response of intestinal cells under in vitro conditions. In the present study, we have established an improvement in the response of the RTgutGC cell line under double seeding conditions which is likely to better mimic the native physiology of the rainbow trout intestine than single seeding. RTgutGC cells expressed the weak presence of neutral mucosubstances characteristic of the distal region of the rainbow trout intestine, while intracellular tight junction formation was evidenced by pronounced staining for ZO-1 and E-caderhin, junctional complexes seen in the electron micrographs (TEM), and comparable TEER to in vivo intestinal reports $\left(50-400 \Omega \mathrm{cm}^{2}\right.$ ) (Jutfelt et al. 2006; Trischitta et al. 1999). Cellular morphology also appeared similar to differentiated enterocytes, which was confirmed as microvilli protrusions through the presence of a filamentous cytoskeleton connecting micro-villi to the underlying monolayer in addition to a fibrillary coat surrounding the protrusions. The retention of functional 
properties of tissue in established cell lines is not unique (Bailey et al. 1996, Lee et al. 2009). Unsurprisingly, this is reported more often in ex vivo primary cultures which are thought to retain more morphological and metabolic comparability to native fish tissues (Stott et al. 2015; Baron et al. 2012; Dowling and Mothersill, 2001). Based on morphological characterisation, the RTgutGC intestinal model appears to be well suited to study uptake and metabolism of metal and other contaminants in a dietary context.

In toxicological investigations using Transwell models, transepithelial resistance is routinely used as an endpoint for both cultured mammalian (Vllasaliu et al. 2014; Leonard et al. 2010; Sambuy et al. 2005) and fish gill epithelia cells (Schnell et al. 2016; Stott et al. 2015; Jonsson et al. 2006; Wood et al. 2002) and more broadly in permeability studies (Buckley et al. 2012). In this study, the TEER profile of the RTgutGC cell line demonstrated comparable resistant and trends to other intestinal derived cell lines with increased resistance following medium change and comparable baseline resistance to in vivo reports $\left(50-400 \Omega \mathrm{cm}^{2}\right.$ ) (Jutfelt et al. 2006; Trischitta et al. 1999). A previous study using the RTgutGC cell line in a Transwell system also reported TEER of approximately $33 \pm 3 \Omega \mathrm{cm}^{2}$ on a 6 well Transwell insert after 21 days (Geppert et al. 2016), while we found a comparable TEER after only 5 days using the double seeding technique (average of $26 \pm 5 \Omega \mathrm{cm}^{2}$ for both L-15:saline solutions). Direct comparison of both studies is difficult, as the larger the membrane or growth area of the culture cup, the lower the TEER measurements. In our study, TEER of RTgutGC cultures demonstrated a moderate increase over time as previously noted by Geppert et al. (2016). Interestingly, this trend in increased TEER was also repeated over time when L-15 medium was exchanged for the experimental solution of L-15:saline, highlighting its tolerance of the application of saline.

Examination of the literature on gill epithelia has attributed increased TEER following replacement of media with water/saline to a closure of ion channels in response to reduced sodium chloride in the apical membrane (Jonsson et al. 2006; Fletcher et al. 2000; Wood and Part 1997). However, in the current study there were minimal changes in sodium concentration between the two exposure solutions and no significant differences between controls and exposures (i.e. no difference between L-15 and L-15:saline). In the context of the intestinal system, sodium is a known osmotic regulator and when combined with a hypertonic solution can have a major impact on cellular resistance and permeability. Indeed, the reason that TEER may have increased in the study model when exposed to saline may be due to the decreased osmolality of the exposure solution (from 274 mOsm in L-15 medium to 204 mOsm in combination solution) and the minimal decrease in sodium levels (approximately $69 \mathrm{nM}$ to $44 \mathrm{nM}$ ). Previous studies support this hypothesis in human intestinal models (Inokuchi et al. 2009; Noach et al. 1994). Using a hypotonic solution of $200 \mathrm{mOsm}$, Noach et al. (1994) observed that after application to HT29-cl19A cells, no significant change in TEER were observed following treatment apically. Instead, a clear increase in resistance was observed $(\sim 144 \%)$, something which the fish intestine and human colorectal adenocarcinoma cell line have in common, although the degree of increase is substantially different between $\mathrm{pH} 7.7(\sim 168 \%)$ and $\mathrm{pH} 7.4(\sim 58 \%)$.

The present study hypothesised that the range of $\mathrm{Cu}$ concentrations used would not induce significant changes in biochemical responses or TEER responses. Previous studies of the uptake of $\mathrm{Cu}$ via the intestine have shown regions of this organ to become supersaturated above a threshold of $\sim 63$ and $157 \mu \mathrm{M}$ for the mid and posterior intestine as demonstrated using the "gut sac" model (Nadella et al. 2006b). It has been postulated that the presence of this threshold (which demonstrates a maximum quantity which the cells can efficiently absorb) will cause a reduction in the toxic action of this metal on the apical/lumen membrane of this organ. Indeed, one drawback with the gut sac approach is the potential for hypoxia in this ex situ model, an area of great interest in vitro with 3D organoid models such as spheroids, where it has been difficult to measure the oxygen in the larger tissue structures (Langan et al. 2016). Using a variety of biochemical parameters (i.e. $\mathrm{LDH}$, cell viability and DNA damage) and later analysis of $\mathrm{Cu}$ uptake, the presence of this supersaturation threshold in the RTgutGC in vitro intestinal model is supported. Generally, LDH is used to detect membrane damage by toxic agents (Acikgöz et al. 2013; Jurišić and Bumbaširević 2008), with LDH activity expected to increase with prolonged toxic exposure through the displacement of calcium ligands and disruption of the membrane permeability as previously demonstrated in fish (Mazon et al. 2004; Bury et al. 1998). Comparable to other toxicological models which support the presence of this supersaturation threshold (Teodorescu et al. 2012, 2008; Antognelli et al. 2006), the current study demonstrates the existence of this threshold through a reduction in both LDH release and lack of significant difference in cell viability (APH assay) suggesting direct comparability to the in vivo tissue. Indeed, this comparability is further enhanced when DNA damage is incorporated into the characterisation. Higher concentrations of $\mathrm{Cu}$ are known to induce DNA damage in teleost species, either through dietary uptake or exposure via media/water (Mustafa et al. 2012; Sandrini et al. 2009). Unlike other studies which aim to induce a genotoxic response with very high concentrations of toxicants, our study was limited to environmentally relevant concentrations (Bakke et al. 2010). It is therefore not surprising that no significant induction of DNA damage was observed using the alkaline comet assay. This is in line 
with original expectations and provides an appropriate baseline for future investigations (Jha 2004). While no significant differences were observed based on $\mathrm{Cu}$ concentrations for any of the biochemical or DNA damage assays used during this study, a clear trend was apparent whereby significant differences were consistently induced as a function of time for both cell viability and genotoxic assays. The observable trend would suggest that these two parameters are inherently correlated and although not investigated in the current study, similar observations have been reported in other animal models and humans using a range of parameters (Dallas et al. 2013; Jha 2008).

In fish, $\mathrm{Cu}$ may be taken up from the diet via the intestine or aqueously (via the gill) and transported to the liver with differing $\mathrm{Cu}$ routes of exposure resulting in differential uptake and transcriptional responses (Mustafa et al. 2012; Minghetti et al. 2008). In long-term exposures, teleost intestine appears to be the second most important organ after liver to accumulate $\mathrm{Cu}$ when exposed through a dietary route (Mustafa et al. 2012). Fundamental understanding of $\mathrm{Cu}$ and other metal accumulation in this organ is therefore an important aspect in ecotoxicological investigations where in vitro models can play an important role. In this context, previous studies using the"gut sac" model have suggested that $\mathrm{Cu}$ uptake differs in different parts or regions of the rainbow trout intestine (Nadella et al. 2006a, b). However, Nadella et al. (2006b) observed no significant differences between mid and posterior intestine after a $2 \mathrm{~h}$ exposure. In our study, $\mathrm{Cu}$ uptake $(3 \mu \mathrm{M})$ in the cell line covers a comparable range for the mid $(\mathrm{pH} 7.7 ; 0.056 \pm$ $\left.0.018 \mathrm{nmol} \mathrm{cm}^{-2} \mathrm{~h}^{-1}\right)$ and posterior $(\mathrm{pH} 7.4 ; 0.062 \pm 0.036$ $\mathrm{nmol} \mathrm{cm}^{-2} \mathrm{~h}^{-1}$ ) in vitro intestinal model to that reported by Nadella et al. (2006b). In their studies, the typical rate was found to be 0.025 and $0.036 \mathrm{nmol} \mathrm{cm}^{-2} \mathrm{~h}^{-1}$ for mid and posterior tissue respectively. Interestingly, uptake rate is only significant over the sampling period which may denote the time necessary for intrinsic homeostatic mechanisms to bring uptake and export rates into equilibrium, as has previously been observed for both fish gill and intestine (Kamunde et al. 2002a). The considerable (but not significant) decline in $\mathrm{Cu}(63 \mu \mathrm{M})$ in the proposed in vitro model at $\mathrm{pH} 7.4$ suggest that the posterior intestine is the most active site of $\mathrm{Cu}$ absorption using this animal replacement system. This suggestion of site of uptake is supported by in vivo observations made by other authors who have identified the posterior intestine as the most active site for unidirectional $\mathrm{Cu}$ uptake in juvenile rainbow trout (Kamunde et al. 2002a, Clearwater et al. 2000, Nadella et al. 2006a).

In general, the mechanisms of gastrointestinal interactions of metals in animals and fish are not clearly understood. It is known that the maintenance of $\mathrm{Cu}$ balance involves the strict regulation of uptake, distribution, detoxification and excretion in fish (Kamunde et al. 2002b). As such, our study investigated five key genes related to xenobiotic defence, metal and oxidative stress. In contrast to our preliminary hypothesis, no significant difference was found between the two $\mathrm{pH}$ conditions or as a function of sampling period. This we believe may be related to the levels of $\mathrm{Cu}$ used in the study and is further supported by observations of Kamunde et al. (2002b) who suggested that intestinal uptake of $\mathrm{Cu}$ may require a threshold for optimal performance, which are less effective when $\mathrm{Cu}$ levels are low. Although no significant differences were observed during our study, it is important to note the presence of metabolising enzymes suggestive of both Phase I (CYP3A) and phase II (GST) biotransformation capacity in this Transwell system. The prevalence of correlations for transcriptional expression of selected genes within our study implies a harmonious metabolic system in this intestinal model capable of first pass metabolism and protection. Previously, van Herwaarden et al. (2009), El-Kattan and Varm (2012) noted that interplay between Pgp and CYP3A, through the sharing of similar substrates and modulators (Hunter and Hirst, 1997), enabled highly efficient metabolism in humans and thus could have a profound effect on first pass elimination of drugs. This trend is also seen in other combinations of genes such as in metallothionein $(m t A)$ and superoxide dismutase $(S O D)$ which were also positively correlated in our study $\left(\mathrm{r}^{2}=0.97\right)$. In agreement with the literature, we propose that these two genes play a key role in protecting and maintaining cellular functionality against metal induced toxicity, with Fang et al. (2010) proposing their function in maintaining cellular metabolic homeostasis. Knowledge of transcriptional expression is a logical addition to a more integrative comparison of in vivo and in vitro studies, and will allow the correct placement and choice of such a model prior to toxicity testing. While other environmentally relevant contaminants (e.g. pharmaceuticals) were not investigated in the current study, the expression of the aforementioned genes opens this model to further testing of other contaminants of concern.

A variety of experimental models have been developed to target toxicology in the aquatic environment and these are readily available to the scientific community. The complexity of these models spans the range of system intricacy from ecosystems to populations, whole animals with different developmental stages, in situ perfusions, ex situ organs, tissue slices, 3D-organoids, co-cultures, primary cultures and mono-cultures of immortalised cells lines such as the RTgutGC. It is axiomatic that each model has both advantages and disadvantages dependent on the scientific need. In order to summarise the current study, we first address where the RTgutGC model falls with other in vitro animal alternative models. Unlike the most commonly cited human in vitro model (i.e. Caco- 2 cell line), the 
RTgutGC cell grown in a Transwell system under double seeding conditions retains comparable morphological characteristics (microvilli formation, metabolic activity in the form of expression of xenobiotic associated genes and similar metabolism of common metals) to the native tissue as demonstrated by Nadella et al. (2006a) without any modification. Although single seeding of Transwell inserts has previously been carried out using the RTgutGC cell line (Geppert et al. 2016) and is common among the culture of Caco-2 Transwell models, TEER is directly comparable between the single and double seeded approach despite differing culture times.

Our study is suggestive of an improved model under double seeding conditions comparable to "gut sac" methodology. This improved model would more readily support high throughout toxicity testing in future research. Indeed, the similarity of uptake kinetics between "gut sac" preparations and in vitro Transwell models (double seeded) is suggestive of a conservation of the $\mathrm{Cu}$ uptake pathway in the cell line. This conservation could allow for an increased understanding of dietary uptake and metabolism of environmentally relevant metals in addition to other contaminants. Indeed, unlike other aquatic models which require higher concentrations of toxicants to detect a toxic response (e.g. Schirmer, 2006), the RTgutGC model has shown itself to be akin to the standard gut sac technique predominantly used in the dietary toxicity studies (e.g. Nadella et al. 2006a, b). Further, to the establishment of comparable morphological developments via TEM, the RTgutGC system is also able to tolerate varying $\mathrm{pH}$ apical saline solutions which simulates in vivo scenarios, a finding previously observed for ex vivo cultures of gill epithelial (Stott et al. 2015). Mimicking the absorptive barriers found in native intestine, the RTgutGC cell line grown on Transwell inserts and modified as outlined in this study provides an avenue for examining the permeability of environmental toxicants in two large sections of the intestine as a replacement or supplement to in vivo animal tests in line with the tenet of the 3Rs. Currently, compounds with a high lipophilicity $(\log$ Kow $<4)$ have to be assessed under regulatory requirements for potential to bioaccumulate in aquatic systems using standard water or dietary routes (Lillicrap et al. 2016; OECD 2012). However, empirical experience would suggest that compounds between log Kow 3 and 4.5 would be of lower risk of accumulation and these could potentially be screened using a Transwell intestinal model such as that illustrated here, rather than using live fish. Our study goes some way towards achieving these goals in line with regulatory commitments and to support the 3 Rs initiatives.

Acknowledgements Ms. Lynne Cooper is thankfully acknowledged for technical assistance. The authors gratefully acknowledge funding from the Biotechnology and Biological Sciences Research Council (BBSRC) and Natural Environment Research Council (NERC) Industrial Partner Award with AstraZeneca; Grant BB/L01016X/1 to ANJ (PI) and SKJ. This work was conducted by LML whilst in receipt of a scholarship from University of Plymouth and the AstraZeneca Safety Health and Environment Research Programme. SFO is an employee of AstraZeneca, a biopharmaceutical company specialised in the discovery, development, manufacturing and marketing of prescription medicines. SFO's work represents an AstraZeneca contribution in kind to the Innovative Medicines Initiative Joint Undertaking under grant agreement no.115735-iPiE: Intelligent led assessment of Pharmaceuticals in the Environment; resources of which are composed of financial contribution from the European Union's Seventh Framework Programme (FP7/2015-2018) and European Federation of Pharmaceutical Industries and Associations (EFPIA) companies' in kind contribution.

\section{Compliance with ethical standards}

Conflict of interest The authors declare that they have no competing interests.

Ethical approval The work presented in this study does not involve any human participants or animal use which requires ethical approval.

Informed consent There were no human participants and no consent was required.

Open Access This article is distributed under the terms of the Creative Commons Attribution 4.0 International License (http://crea tivecommons.org/licenses/by/4.0/), which permits unrestricted use, distribution, and reproduction in any medium, provided you give appropriate credit to the original author(s) and the source, provide a link to the Creative Commons license, and indicate if changes were made.

\section{References}

Acikgöz A, Giri S, Cho M, Bader A (2013) Functional analysis of hepatocyte sperhoids generated on poly-HEMA-treated surfaces under the influence of fetal calf serum and nonparenchymal cells. Biomolecules 3:242-269. doi:10.3390/biom3010242

Alam MA, Al-Jenoobi FI, Al-Mohizea AM (2012) Everted gut sac model as a tool in pharmaceutical research: Limitations and applications. J Pharm Pharmacol 64(3):326-336. doi:10.1111/j. 2042-7158.2011.01391.x

Anna O, Monika L, Wodzimierz G, Katarzyna C (2003) New rapid method of Caco-2 cell differentiation. Methodol Nov Food Eval Pol J Food Nutr Sci 12(48 61):60-64

Antognelli C, Baldracchini F, Frosini R, Piazzoli A, Talesa V, Giovannini E (2006) Effects of exposure to Scapharca inaequivalvis. Biochem Syst Ecol 34(4):275-281. doi:10.1016/j. bse.2005.11.008

Bailey CA, Bryla P, Malick A (1996) The use of the intestinal epithelial cell culture model, Caco-2, in pharmaceutical development. Adv Drug Deliv Rev 22(1-2):85-103. doi:10.1016/S0169409X(96)00416-4

Bakke AM, Glover C, Krogdahl ^̊ (2010) Feeding, digestion and absorption of nutrients. In: Grosell M, Farrell AP, Braune CJ (eds) Fish Physiology: The multifunctional Gut of Fish. Academic Press, United States, chap 2, pp 57-110 
Baron MG, Purcell WM, Jackson SK, Owen SF, Jha AN (2012) Towards a more representative in vitro method for fish ecotoxicology: morphological and biochemical characterisation of threedimensional spheroidal hepatocytes. Ecotoxicology 21 (8):2419-2429. doi:10.1007/s10646-012-0965-5

Buckley ST, Fischer SM, Fricker G, Brandl M (2012) In vitro models to evaluate the permeability of poorly soluble drug entities: Challenges and perspectives. Eur J Pharm Sci 45(3):235-250. doi:10.1016/j.ejps.2011.12.007

Burden N, Creton S, Weltje L, Maynard SK, Wheeler JR (2014) Reducing the number of fish in bioconcentration studies with general chemicals by reducing the number of test concentrations. Regul Toxicol Pharmacol 70(2):442-445. doi:10.1016/j. yrtph.2014.08.008

Burden N, Benstead R, Clook M, Doyle I, Edwards P, Maynard SK, Ryder K, Sheahan D, Whale G, van Egmond R, Wheeler JR, Hutchinson TH (2015a) Advancing the 3Rs in regulatory ecotoxicology: a pragmatic cross-sector approach. Integr Environ Assess Manag 12(3):417-421. doi:10.1002/ieam.1703

Burden N, Sewell F, Chapman K (2015b) Testing chemical safety: what Is needed to ensure the widespread application of nonanimal approaches? PLoS Biol 13(5):1-8. doi:10.1371/journal. pbio. 1002156

Bury NR, Jie L, Flik G, Lock RA, Bonga SE (1998) Cortisol protects against copper induced necrosis and promotes apoptosis in fish gill chloride cells in vitro. Aquat Toxicol 40(2-3):193-202. doi:10.1016/S0166-445X(97)00051-9

Castaño A, Bols N, Braunbeck T, Dierickx P, Halder M, Isomma B, Kawahara K, Lee LEJ, Mothersill C, Pärt P, Sintes JR, Rufi H, Smith R, Wood C, Segner H (2003) The use of fish cells in ecotoxicology. Atla Altern to Lab Anim 31(3):317-351

Catherine Tee P, Janice Wong Y, Sherry JP, Bols NC (2011) Effect of acid blue 80 , an anthracenedione dye, on rainbow trout liver, gill and gut cells in vitro. Ecotoxicol Environ Saf 74(7):1874-1878. doi:10.1016/j.ecoenv.2011.07.026

Clearwater SJ, Baskin SJ, Wood CM, McDonald DG (2000) Gastrointestinal uptake and distribution of copper in rainbow trout. $\mathrm{J}$ Exp Biol 203(16):2455-2466

Dallas LJ, Bean TP, Turner A, Lyons BP, Jha AN (2013) Oxidative DNA damage may not mediate Ni-induced genotoxicity in marine mussels: Assessment of genotoxic biomarkers and transcriptional responses of key stress genes. Mutat Res - Genet Toxicol Environ Mutagen 754(1-2):22-31. doi:10.1016/j.mrgentox.2013. 03.009

Dixit P, Jain DK, Dumbwani J (2012) Standardization of an ex vivo method for determination of intestinal permeability of drugs using everted rat intestine apparatus. J Pharmacol Toxicol Methods 65 (1):13-17. doi:10.1016/j.vascn.2011.11.001

Donnachie RL, Johnson AC, Sumpter JP (2016) A rational approach to selecting and ranking some pharmaceuticals of concern for the aquatic environment and their relative importance compared with other chemicals. Environ Toxicol Chem 35(4):1021-1027. doi:10.1002/etc. 3165

Dowling K, Mothersill C (2001) The further development of rainbow trout primary epithelial cell cultures as a diagnostic tool in ecotoxicology risk assessment. Aquat Toxicol 53(3-4):279-289. doi:10.1016/S0166-445X(01)00172-2

Eisenbrand G, Pool-Zobel B, Baker V, Balls M, Blaauboer BJ, Boobis A, Carere A, Kevekordes S, Lhuguenot JC, Pieters R, Kleiner J (2002) Methods of in vitro toxicology. Food Chem Toxicol 40:193-236. doi:10.1016/S0278-6915(01)00118-1

El-Kattan A, Varm M (2012) Oral absorption, intestinal metabolism and human oral bioavailability. In: Paxton J (ed) Top. Drug Metab., InTech, chap Oral Absor, pp 1-35. doi:10.5772/31087

Fang Y, Yang H, Wang T, Liu B, Zhao H, Chen M (2010) Metallothionein and superoxide dismutase responses to sublethal cadmium exposure in the clam Mactra veneriformis. Comp Biochem Physiol Part C Toxicol Pharmacol 151(3):325-333. doi:10.1016/j.cbpc.2009.12.005

Fard MRS, Weisheit C, Poynton SL (2007) Does pH affect microhabitat preference of the pathogenic diplomonad Spironucleus Salmonis in the intestine of rainbow trout (Oncorhynchus mykiss) ? Dis Aquat Organ 76(May):126-127

Ferruzza S, Rossi C, Scarino ML, Sambuy Y (2012) A protocol for differentiation of human intestinal Caco-2 cells in asymmetric serum-containing medium. Toxicol Vitr pp 8-11, 10.1016/j.tiv. 2012.01.008

Fierro-Castro C, Barrioluengo L, López-Fierro P, Razquin B, Carracedo B, Villena AJ (2012) Fish cell cultures as in vitro models of pro-inflammatory responses elicited by immunostimulants. Fish Shellfish Immunol 33(2):289-400. doi:10.106/j.fsi.2012.05.019

Fischer S, Loncar J, Zaja R, Schnell S, Schirmer K, Smital T, Luckenbach $\mathrm{T}$ (2011) Constitutive mRNA expression and protein activity levels of nine $\mathrm{ABC}$ efflux transporters in seven permanent cell lines derived from different tissues of rainbow trout (Oncorhynchus mykiss). Aquat Toxicol 101(2):438-446. doi:10.1016/j.aquatox.2010.11.010

Fletcher M, Kelly SP, Pärt P, O’Donnell MJ, Wood CM (2000) Transport properties of cultured branchial epithelia from freshwater rainbow trout: a novel preparation with mitochondria-rich cells. J Exp Biol 203(Pt 10):1523-1537

Friedrich J, Eder W, Castaneda J, Doss M, Huber E, Ebner R, KunzSchughart La (2007) A reliable tool to determine cell viability in complex 3-d culture: the acid phosphatase assay. J Biomol Screen Off J Soc Biomol Screen 12(7):925-937. doi:10.1177/ 1087057107306839

Friedrich J, Seidel C, Ebner R, Kunz-Schughart La (2009) Spheroidbased drug screen: considerations and practical approach. Nat Protoc 4(3):309-324. doi:10.1038/nprot.2008.226

Fryer JL, Lannan CN (1994) Three decades of fish cell culture: a current listing of cell lines derived from fishes. J Tissue Cult Methods 16(2):87-94. doi:10.1007/BF01404816

Galkin A, Pakkanen J, Vuorela P (2008) Development of an automated 7-day 96-well Caco- 2 cell culture model. Pharmazie 63 (6):464-469. doi:10.1691/ph.2008.7855

Gan LSL, Thakker DR (1997) Applications of the Caco-2 model in the design and development of orally active drugs: elucidation of biochemical and physical barriers posed by the intestinal epithelium. Adv Drug Deliv Rev 23(1-3):77-98. doi:10.1016/ S0169-409X(96)00427-9

Gendron RL, Armstrong E, Paradis H, Haines L, Desjardins M, Short CE, Clow Ka, Driedzic WR (2011) Osmotic pressure-adaptive responses in the eye tissues of rainbow smelt (Osmerus mordax). Mol Vis 17(December 2010):2596-604

Geppert M, Sigg L, Schirmer K (2016) A novel two-compartment barrier model for investigating nanoparticle transport in fish intestinal epithelial cells. Environ Sci Nano 3:388-395. doi:10. 1039/C5EN00226E

Gillespie JL, Anyah A, Taylor JM, Marlin JW, Taylor TA (2016) A versatile method for immunofluorescent staining of cells cultured on permeable membrane inserts. Med Sci Monit Basic Res 22:91-94. doi:10.12659/MSMBR.900656

Grosell M, Farell A, Brauner C (eds) (2010) The Multifunctional gut of fish, fish physi edn. Academic Press, United States

Gupta V, Doshi N, Mitragotri S (2013) Permeation of insulin, calcitonin and exenatide across caco-2 monolayers: measurement using a rapid, 3-Day System. PLoS One 8(2). doi:10.1371/journa 1.pone. 0057136

Handy RD, Musonda MM, Phillips C, Falla SJ (2000) Mechanisms of gastrointestinal copper absorption in the African walking catfish: copper dose-effects and a novel anion-dependent pathway in the intestine. J Exp Biol 203(Pt 15):2365-2377 
Heikkinen AT, Korjamo T, Mönkkönen J (2010) Modelling of drug disposition kinetics in in vitro intestinal absorption cell models. Basic and Clinical. Pharmacol Toxicol 106(3):180-188

Hubatsch I, Ragnarsson EGE, Artursson P (2007) Determination of drug permeability and prediction of drug absorption in Caco-2 monolayers. Nat Protoc 2(9):2111-9. doi:10.1038/nprot.2007. 303

Hunter J, Hirst BH (1997) Intestinal secretion of drugs. The role of Pglycoprotein and related drug efflux systems in limiting oral drug absorption. Adv Drug Deliv Rev 25(2-3):129-157. doi:10.1016/ S0169-409X(97)00497-3

Hutchinson T (2008) Intelligent testing strategies in ecotoxicology: approaches to reduce and replace fish and amphibians in toxicity testing. Intell Test Strateg Ecotoxicol 14:1-11

Inokuchi H, Takei T, Aikawa K, Shimizu M (2009) The effect of hyperosmosis on paracellular permeability in Caco-2 cell monolayers. Biosci Biotechnol Biochem 73(2):328-334. doi:10.1271/ bbb. 80538

Jeram S, Riego Sintes JM, Halder M, Baraibar Fentanes J, SokullKlüttgen B, Hutchinson TH (2005) A strategy to reduce the use of fish in acute ecotoxicity testing of new chemical substances notified in the European Union. Regul Toxicol Pharmacol 42 (2):218-224. doi:10.1016/j.yrtph.2005.04.005

Jha AN (2004) Genotoxicological studies in aquatic organisms: an overview. Mutat Res -Fundam Mol Mech Mutagen 552(12):1-17. doi:10.1016/j.mrfmmm.2004.06.034

Jha AN (2008) Ecotoxicological applications and significance of the comet assay. Mutagenesis 23(3):207-221. doi:10.1093/mutage/ gen014

Jonsson ME, Carlsson C, Smith RW, Pärt P (2006) Effects of copper on CYP1A activity and epithelial barrier properties in the rainbow trout gill. Aquat Toxicol 79:78-86. doi:10.1016/j.aquatox. 2006.05.006

Jurišić V, Bumbaširević V (2008) In vitro assays for cell death determination. Arch Oncol 16(3-4):49-54. doi:10.2298/ AOO0804049J

Jutfelt F (2011) Barrier Function of the Gut. In: Farrell AP (ed) Encycl. Fish Physiol. From Genome to Environ., vol 2, Elsevier Inc., pp 1322-1331. doi:10.1016/B978-0-12-374553-8.00068-X

Jutfelt F, Olsen RE, Glette J, Ringo E, Sundell K (2006) Translocation of viable Aeromonas salmonicida across the intestine of rainbow trout, Oncorhynchus mykiss (Walbaum). J Fish Dis 29 (5):255-262. doi:10.1111/j.1365-2761.2006.00715.x

Kamunde C, Clayton C, Wood CM (2002a) Waterborne vs. dietary copper uptake in rainbow trout and the effects of previous waterborne copper exposure. Am J Physiol Regul Integr Comp Physiol 283(1):R69-R78. doi:10.1152/ajpregu.00016.2002

Kamunde C, Grosell M, Higgs D, Wood CM (2002b) Copper metabolism in actively growing rainbow trout (Oncorhynchus mykiss): interactions between dietary and waterborne copper uptake. J Exp Biol 205(Pt 2):279-290

Kawano A, Kales SC, Fujiki K, DeWitte-Orr SJ, Dixon B, Lee LEJ, Bols NC (2010) A comparison of rainbow trout cell lines for their expression of the major histocompatibility complex genes and the induction of beta-2-microglobulin by dsRNA. Fish Shellfish Immunol 29(2):312-318. doi:10.1016/j.fsi.2010.04.007

Kawano a, Haiduk C, Schirmer K, Hanner R, Lee LEJ, Dixon B, Bols NC (2011) Development of a rainbow trout intestinal epithelial cell line and its response to lipopolysaccharide. Aquac Nutr 17 (2). doi:10.1111/j.1365-2095.2010.00757.x

Klinck JS, Wood CM (2011) In vitro characterization of cadmium transport along the gastrointestinal tract of freshwater rainbow trout (Oncorhynchus mykiss). Aquat Toxicol 102(1-2):58-72. doi:10.1016/j.aquatox.2010.12.009

Kumaravel TS, Jha AN (2006) Reliable Comet assay measurements for detecting DNA damage induced by ionising radiation and chemicals. Mutat Res-Genet Toxicol Environ Mutagen 605(12):7-16. doi:10.1016/j.mrgentox.2006.03.00

Lakra WS, Swaminathan TR, Joy KP (2011) Development, characterization, conservation and storage of fish cell lines: a review. Fish Physiol Biochem 37(1):1-20. doi:10.1007/s10695-0109411-x

Langan LM, Dodd NJF, Owen SF, Purcell WM, Jackson SK, Jha AN (2016) Direct measurements of oxygen gradients in spheroid culture system using electron parametric resonance oximetry. PLoS ONE 11(2):e0149,492. doi:10.1371/journal.pone.0149492

Lee LEJ, Dayeh VR, Schirmer K, Bols NC (2009) Applications and potential uses of fish gill cell lines: examples with RTgill-W1. Vitr Cell Dev Biol-Anim 1-8. doi:10.1007/s11626-008-9173-2

Leonard E, Nadella S, Bucking C, Wood C (2009) Characterization of dietary $\mathrm{Ni}$ uptake in the rainbow trout, Oncorhynchus mykiss. Aquat Toxicol 93(4):205-216. doi:10.1016/j. aquatox.2009.05.002

Leonard F, Collnot EM, Lehr CM (2010) A three-dimensional coculture of enterocytes, monocytes and dendritic cells to model inflamed intestinal mucosa in vitro. Mol Pharm 7 (6):2103-2119. doi:10.1021/mp1000795

Lillicrap A, Springer T, Tyler CR (2016) A tiered assessment strategy for more effective evaluation of bioaccumulation of chemicals in fish. Regul. Toxicol Pharmacol 75:20-26

Liu Y, Hu M (2002) Absorption and metabolism of flavonoids in the Caco-2 cell culture model and a perfused rat intestinal model. Drug Metab Dispos 30(4):370-377. doi:10.1124/dmd.30.4.370

Mariappan TT, Singh S (2004) Evidence of efflux-mediated and saturable absorption of rifampicin in rat intestine using the ligated loop and everted gut sac techniques. Mol Pharm 1(5):363-367

Mazon aF, Nolan DT, Lock RaC, Fernandes MN, Wendelaar Bonga SE (2004) A short-term in vitro gill culture system to study the effects of toxic (copper) and non-toxic (cortisol) stressors on the rainbow trout, Oncorhynchus mykiss (Walbaum). Toxicol Vitr 18 (5):691-701. doi:10.1016/j.tiv.2004.03.008

Minghetti M, Drieschner C, Bramaz N, Schug H, Schirmer K (2017) A fish intestinal epithelial barrier model established from the rainbow trout (Oncorhynchus mykiss) cell line, RTgutGC. Cell Biol Toxicol 1-17. doi:10.1007/s10565-017-9385-x

Minghetti M, Leaver MJ, Carpene' E, George SG (2008) Copper transporter 1, metallothionein and glutathione reductase genes are differentially expressed in tissues of sea bream (Sparus aurata) after exposure to dietary or waterborne copper. Comp Biochem Physiol C Toxicol Pharmacol 147(4):450-9. doi:10.1016/j.cbpc. 2008.01.014

Mustafa SA, Davies SJ, Jha AN (2012) Determination of hypoxia and dietary copper mediated sub-lethal toxicity in carp, Cyprinus carpio, at different levels of biological organisation. Chemosphere 87(4):413-422

Nadella S, Hung C, Wood C (2011) Mechanistic characterization of gastric copper transport in rainbow trout. J Comp Physiol B Biochem Syst Environ Physiol 181(1):27-41. doi:10.1007/ s00360-010-0510-x

Nadella SR, Bucking C, Grosell M, Wood CM (2006a) Gastrointestinal assimilation of $\mathrm{Cu}$ during digestion of a single meal in the freshwater rainbow trout (Oncorhynchus mykiss). Comp Biochem Physiol - C Toxicol Pharmacol 143(4):394-401. doi:10.1016/j.cbpc.2006.04.012

Nadella SR, Grosell M, Wood CM (2006b) Physical characterization of high-affinity gastrointestinal $\mathrm{Cu}$ transport in vitro in freshwater rainbow trout Oncorhynchus mykiss. J Comp Physiol B Biochem Syst Environ Physiol 176(8):793-806. doi:10.1007/s00360-0060101-z

Nadella SR, Grosell M, Wood CM (2007) Mechanisms of dietary Cu uptake in freshwater rainbow trout: Evidence for $\mathrm{Na}$-assisted $\mathrm{Cu}$ transport and a specific metal carrier in the intestine. J Comp 
Physiol B Biochem Syst Environ Physiol 177(4):433-446. doi:10.1007/s00360-006-0142-3

Natoli M, Leoni BD, D'Agnano I, D'Onofrio M, Brandi R, Arisi I, Zucco F, Felsani A (2011) Cell growing density affects the structural and functional properties of Caco-2 differentiated monolayer. J Cell Physiol 226(6):1531-1543. doi:10.1002/ jcp. 22487

Nehls S, Segner H (2005) Comet assay with the fish cell line rainbow trout gonad-2 for in vitro genotoxicity testing of xenobiotics and surface waters. Environ Toxicol Chem 24(8):2078-2087. doi:10. 1897/04-301R.1

Noach AB, Sakai M, Blom-Roosemalen MC, de Jonge HR, de Boer AG, Breimer DD (1994) Effect of anisotonic conditions on the transport of hydrophilic model compounds across monolayers of human colonic cell lines. J Pharmacol Exp Ther 270 (3): $1373-1380$

OECD (2012) Test No 305: Bioaccumulation in Fish : Aqueous and Dietary Exposure. doi:10.1787/9789264185296-en

Ojo Aa, Wood CM (2007) In vitro analysis of the bioavailability of six metals via the gastrointestinal tract of the rainbow trout (Oncorhynchus mykiss). Aquat Toxicol 83(1):10-23. doi:10.1016/j.aqua tox.2007.03.006

Papis E, Davies SJ, Jha AN (2011) Relative sensitivity of fish and mammalian cells to the antibiotic, trimethoprim: cytotoxic and genotoxic responses as determined by neutral red retention, Comet and micronucleus assays. Ecotoxicology 20(1):208-217. doi:10.1007/ s10646-010-0572-2

Parton A, Norrgren L, Bergstrom E, Sjoberg P (1993) Primary cultures of epithelial cells from Rainbow trout gills. J Exp Biol 175:219-232. doi:10.1016/0141-1136(95)98426-D

Pfaffl MW (2001) A new mathematical model for relative quantification in real-time RT-PCR. Nucleic Acids Res 29(9):e45. doi:10. 1093/nar/29.9.e45

Rachlin JW, Perlmutter A (1968) Fish cells in culture for study of aquatic toxicants. Water Res 2(6):409-414. doi:10.1016/00431354(68)90060-2

Raisuddin S, Jha AN (2004) Relative sensitivity of fish and mammalian cells to sodium arsenate and arsenite as determined by alkaline single-cell gel electrophoresis and cytokinesis-block micronucleus assay. Environ Mol Mutagen 44(1):83-89. doi:10.1002/em.20027

Ramakers C, Ruijter JM, Lekanne Deprez RH, Moorman AFM (2003) Assumption-free analysis of quantitative real-time polymerase chain reaction (PCR) data. Neurosci Lett 339(1):62-66. doi:10. 1016/S0304-3940(02)01423-4

Rao X, Huang X, Zhou Z, Lin X (2013) An improvement of the 2 (-delta delta $\mathrm{CT}$ ) method for quantitative real-time polymerase chain reaction data analysis. Biostat Bioinforma Biomath 3 (3):71-85. doi:10.1016/j.biotechadv.2011.08.021.Secreted

Reeves JF, Davies SJ, Dodd NJF, Jha AN (2008) Hydroxyl radicals $(\cdot \mathrm{OH})$ are associated with titanium dioxide $(\mathrm{TiO} 2)$ nanoparticleinduced cytotoxicity and oxidative DNA damage in fish cells. Mutat Res - Fundam Mol Mech Mutagen 640(1-2):113-122. doi:10.1016/j.mrfmmm.2007.12.010

RStudio T (2015) RStudio: Integrated Development Environment for R. RStudio Inc., Boston, MA

Sambuy Y, De Angelis I, Ranaldi G, Scarino ML, Stammati a, Zucco $\mathrm{F}$ (2005) The Caco-2 cell line as a model of the intestinal barrier: influence of cell and culture-related factors on Caco- 2 cell functional characteristics. Cell Biol Toxicol 21(1):1-26. doi:10.1007/ s10565-005-0085-6

Sandrini JZ, Bianchini A, Trindade GS, Nery LEM, Marins LFF (2009) Reactive oxygen species generation and expression of DNA repair-related genes after copper exposure in zebrafish
(Danio rerio) ZFL cells. Aquat Toxicol 95(4):285-291. doi:10.1016/j.aquatox.2009.02.016

Schirmer K (2006) Proposal to improve vertebrate cell cultures to establish them as substitutes for the regulatory testing of chemicals and effluents using fish. Toxicology 224(3):163-83. doi:10. 1016/j.tox.2006.04.042

Schnell S, Stott LC, Hogstrand C, Wood CM, Kelly SP, Pärt P, Owen SF, Bury NR (2016) Procedures for the reconstruction, primary culture and experiment use of rainbow trout gill epithelia. Nat Protoc 11(3):490-498. doi:10.1038/nprot.2016.029

Scholz S, Segner H (1999) Induction of CYP1A in primary cultures of rainbow trout (Oncorhynchus mykiss) liver cells: concentrationresponse relationships of four model substances. Ecotoxicol Environ Saf 43(3):252-260. doi:10.1006/eesa.1999.1786

Scholz S, Renner P, Belanger SE, Busquet F, Davi R, Demeneix BA, Denny JS, Léonard M, McMaster ME, Villeneuve DL, Embry MR (2013) Alternatives to in vivo tests to detect endocrine disrupting chemicals (EDCs) in fish and amphibians-screening for estrogen, androgen and thyroid hormone disruption. Crit Rev Toxicol 43(1):45-72. doi:10.3109/10408444.2012.737762

Stott LC, Schnell S, Hogstrand C, Owen SF, Bury NR (2015) A primary fish gill cell culture model to assess pharmaceutical uptake and efflux: evidence for passive and facilitated transport. Aquat Toxicol 159:127-137. doi:10.1016/j.aquatox.2014.12.007

Teodorescu D, Munteanu CM, Staicu AC, Dinischiotu A (2008) Ldh activity in copper in-toxication of Carassius Auratus Gibelio gills and intestine. Sci Pap Anim Sci Biotechnol 41(2):169-174

Teodorescu D, Munteanu CM, Staicu AC, Dinischiotu A (2012) Changes in lactate dehydrogenase activity in Carassius Auratus Gibelio (L. Pysces) kidney, gills and intestine induced by acute exposure to copper. Rom Biotechnol Lett 17(6):7873-7880

Trischitta F, Denaro MG, Faggio C (1999) Effects of acetylcholine, serotonin and noradrenalin on ion transport in the middle and posterior part of Anguilla anguilla intestine. J Comp Physiol - B Biochem Syst Environ Physiol 169(6):370-376. doi:10.1007/ s003600050233

van Herwaarden AE, van Waterschoot RaB, Schinkel AH (2009) How important is intestinal cytochrome P450 3A metabolism? Trends Pharmacol Sci 30(5):223-227. doi:10.1016/j.tips.2009.02.003

Vandesompele J, De Preter K, Pattyn F, Poppe B, Van Roy N, De Paepe A, Speleman F (2002) Accurate normalization of real-time quantitative RT-PCR data by geometric averaging of multiple internal control genes. Genome Biol 3(7). doi:10.1186/gb-20023-7-research0034

Vllasaliu D, Falcone FH, Stolnik S, Garnett M (2014) Basement membrane influences intestinal epithelial cell growth and presents a barrier to the movement of macromolecules. Exp Cell Res 323 (1):218-231. doi:10.1016/j.yexcr.2014.02.022

Wolf K, Quimby MC (1962) Established eurythermic line of fish cells in vitro. Science 135(3508):1065-6. doi:10.1126/science.135. 3508.1065

Wood C, Part P (1997) Cultured branchial epithelia from freshwater fish gills. J Exp Biol 200(Pt 6):1047-59

Wood CM, Eletti B, Pärt P (2002) New methods for the primary culture of gill epithelia from freshwater rainbow trout. Fish Physiol Biochem 26(4):329-344. doi:10.1023/B: FISH.0000009262.45438.79

Yamashita S, Konishi K, Yamazaki Y, Taki Y, Sakane T, Sezaki H, Furuyama Y (2002) New and Better aprotocols for a short-term Caco-2 cell culture system. J Pharm Sci 91(3):669-679. doi:10. 1002/jps. 10050

Yuan JS, Reed A, Chen F, Stewart CN (2006) Statistical analysis of real-time PCR data. BMC Bioinformatics 7:85. doi:10.1186/ $1471-2105-7-85$ 